\title{
عقد التوحيد فى تحقيق كلمة التوحيد \\ ( دراسة فيلولوجية ) \\ إعداد :
}

\section{إسماعيلية}

\section{تجريد}

إنّ تحقيق التراث هو أمر جليل، يحتاج من الجهد والعناية إلى أكثر مما يحتاج إليه التأليف. وبالجملة فالتحقيق عمل علمي دقيق، قائم على البحث والنظر، والرجوع إلى المصادر والمراجع، والاجتهاد والتوفيق وإبداء الرأي، وإحياء تراث الآباء والأجداد، لذا يحاول الباحث تحقيق التراث بجهد وعناية

وفى هذه المناسبة، إخترت إحدى المخطوطات لدراسة النص ووصفه، وتقديم نبذة عن حياة مؤلف المخطوطة ثم ترجمة النص إلى اللغة الإندونيسية حتى تعم الفائدة، ومعرفة الأفكار الهامة منها.

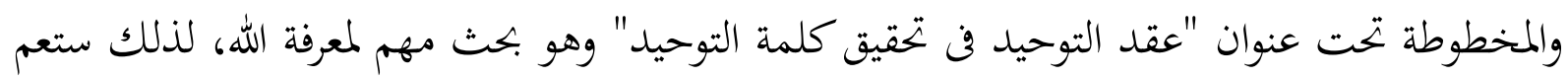
الفائدة بعد دراسة النص لأن له أثر كبير في حياة الناس. والمخطوطات لها أهمية بالغة في المحافظة على التراث القديم فن العالم وتؤدي دراسة المخطوطات إلى تواصل الأجيال وترابط الأمم وازدهار الحضارات. الكلمات المفاتحية: عقد التوحيد في تحقيق كلمة التوحيل، دراسة فيلولوجية، الأفكار الهامة.

Abstract

Mencapai warisan adalah Jalil, membutuhkan usaha dan peduli untuk lebih dari dia perlu Karangan. Penyelidikan grosir adalah karya ilmiah menyeluruh, berdasarkan penelitian dan pertimbangan, dan kembali ke sumber dan referensi, dan ketekunan, konsiliasi dan menyatakan pendapat, dan kebangkitan warisan dari nenek moyang kita, sehingga peneliti sedang mencoba untuk mencapai sangat usaha warisan dan perhatian.

Pada kesempatan ini, saya memilih salah satu naskah untuk mempelajari teks dan deskripsi, dan memberikan gambaran tentang kehidupan penulis naskah dan kemudian menerjemahkan teks ke dalam bahasa Indonesia sehingga manfaat, dan belajar yang ide-ide penting. Naskah berjudul "Unifikasi diadakan dalam pencapaian kata Tauhid" Ini adalah pencarian penting bagi pengetahuan tentang Allah, sehingga bunga akan dilakukan setelah mempelajari teks karena memiliki dampak yang signifikan terhadap kehidupan masyarakat.

Naskah merupakan hal yang sangat penting dalam pelestarian warisan kuno dunia dan memimpin studi naskah untuk kelangsungan generasi dan saling ketergantungan bangsa dan peradaban berkembang.

kata kunci: standardisasi kontrak dalam mewujudkan konsolidasi kata, studi Velologih, ide-ide penting. 
المخطوطة هي عبارة عن نسخة مكتوبة باليد. 1 والمخطوطات بالمفهوم العام تشمل كل مكتوب عليه بخط اليد، سواء أكان من الأحجار أم كان من الأخشاب والجلود وسعف النخيل والورق والقماث. 2 والمخطوطات بمفهومها الخاص : كتب أو كراسات أو أوراق خطت باليد في عصر ما قبل الطباعة أو عصر الطباعة بيد أهفا لم تطبع.

1 عبد الهادى الفضلى، تحقيق التراث، جدة: مكتبة العلم

$$
\text { 1682، ط.1.، ص.34 }
$$

2 محمود حامد عثمان، المرثلد المى تحقيق المخطوطات

$$
\text { العربية، الرياض : دار الزاحم، 2003م. }
$$

$$
\begin{aligned}
& 3 \text { البحث العلمي بين دراسة الموضوعات وتمقيق } \\
& \text { المخطوطات ص.36. }
\end{aligned}
$$

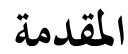

والمخطوطة كلمة ذات مدلول كبير، لا يعرف قيمتها إلا من عايش المخطوط وعاينه، ومن درس المخطوطات وحادثها وحاورها، فكان بينه وبينها صداقة حميمة صادقة. 4 والحديث عن المخطوط العربى حديث شاق، والحديث عنه خلال القرون الأولى من تاريخه أكبر مشقّة وأشد عسرا لأنّ الزمن لم لم يبق من أثار تلك الفترة إلا نماذج قليلة وجذاذات مبعثرة لا يمكن أن نخرج من دراستها برأى قاطع أو حقيقة ثابتة، فإذا تركنا النماذج إلى مصادر التاريخ وكتب الحضارة العربية لم نجد فيها غير قليل من الأخبار بغير ضابط ولا منهج واضح حتى فن سردها. 5

2 مروة, اسماعيل، اسماعيل، في المخطوطات العربية، بيروت، لبنان : دار الفكر المعاصر. 3 عبد الستار الحلوجى، المخطوط العربي، القاهرة: الدار المصرية اللبنانية 1423ه، ط.1، ص.13. 
للمخطوطات أهمية بالغة، لأنما تربط

حاضر الأمم بماضيها ليكون المستقبل مبنيا على حاضر موصول بماض زاهر، وهذا يؤدي إلى تواصل الأجيال وترابط الأمم وازدهار

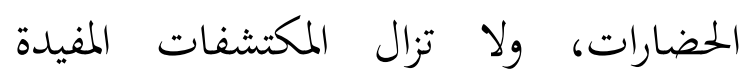
نكتشف عن طريق المخطوطات إذ كان القدماء يسجلون مظاهر حضارتم من ثقافة وعادات وتقاليد وأخلاق وعقائد...على كل

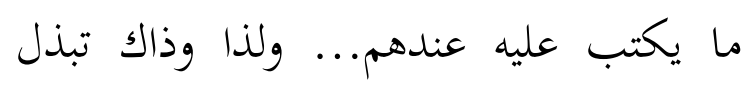
الأمم كل مرتخص ونفيس من أجل الحفاظ على خخطوطاتما في شتي مناحي العلم والمعرفة. 6 وفن إندونيسيا مخطوطات عديدة

كانت موجودة في مختلف الأقاليم ومحفوظة في مكتبات عديدة وأكثرها يوجد في المكتبة القومية بإندونيسيا. ونظرا لأهمية دراسة

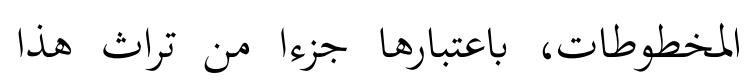

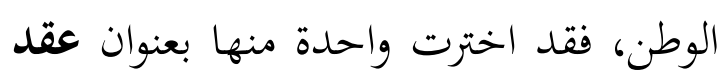
التوحيد في تحقيق كلمة التوحيد لمؤلفها عطاء الله بن أحمد بن عطاء الله بن أحمد المصرى الأزهرى مكتوبة باللغة العربية، ويعود تاريخ المخطوطة إلى عام 1180 هـ. لتكون موضوعا للبحث في هذه الدراسة.

6 البحث العلمي، المرجع السابق، ص 37.
هذا الموضوع يحتاج إلى جهد كبير

خاصة لأنّ أكثر أوراق المخطوطة فاسدة والكتابة غير واضحة بسبب مرور الزمن. وقد اخترت هذه المخطوطة لدراستها تم ترجمتها إلى اللغة الإندونيسية لأنّ علم التوحيد مهمّ ومطلوب لنا خاصة لمعرفة كيفية التقرب إلى الله. وحسب ماذكر المؤلف في مطلع النص أن هذه رسالة لطيفة وفائدة شريفة لقبتها بعقد التوحيد. د ـمنهج التحقيق

نظرا لوجود نسختين، فسأقوم بعمل دراسة مقارنة لاختيار النسخة الكاملة والأفضل. كما سأعتمد على منهج ستاندار

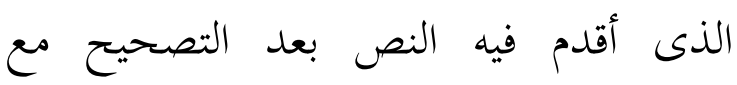

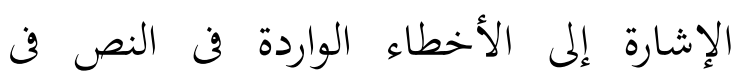
الهوامش.7 واعتمدت في تحقيق نص عقد الإند التوحيد في تحقيق كلمة التوحيد على المخطوطة الواحدة، واعتبر المخطوطة 473 عربي أساسا للتحقيق، وإلى جانب ذلك حاولت أن أبذل كل ما ورد في المخطوطة من الآيات القرآنية

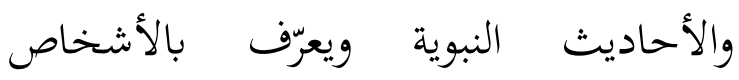

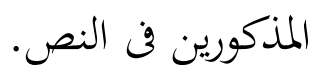
ونظرا لما ينبغى للنص المحقق من أن يكون قابلا لأن يقرأ، أبين اللوازم القلمية

7 Nabilah Lubis, Naskah, Teks Dan Metode Penelitian Filologi, (Jakarta: Yayasan Media Alo Indonesia, 2001), H. 96. 
للنساخ وأستبعدها من الجهاز النقدى، فلا تدخل فيها على أها اختلافات في القراءة، أعنى كل العناية بعلامات الترقيم وفقا لوظائفها

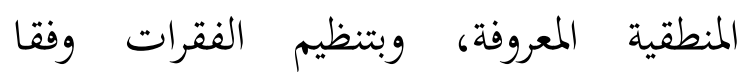
لوحداتا الفكرية، وفيما يلي إشارات التحقيق: 1

$$
\text { القرآنية }
$$

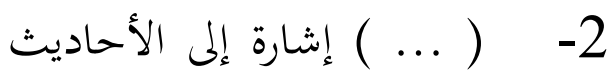

$$
\text { النبوية }
$$

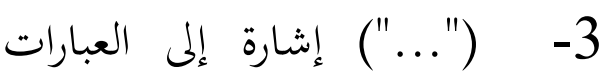

$$
\text { المنقولة عن أقوال الأشخاص إلتاره }
$$

\section{التعريف بالمؤلف و وصف المخطوطة}

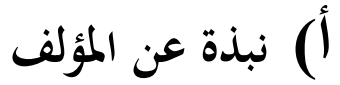

عطاء الله المصرى (كان حيا في 1170هـ او 1757م). عطاء الله بن أحمد بن عطاء الله بن أحمد المصرى الأزهرى الشافعى، نزيل مكة، وهو أديب مشارك في له بعض العلوم. 8 مؤلفاته 1) غاية الرفع الى ذروة الوضغ ثم شرحها 2) تحفة الخلان بشرح نصيحة الإخوان، فرغ من تأليفها سنة 1170هـ

8عمر رضا كحاله، معجم المؤلفين، تراجم مصنفى الكتب

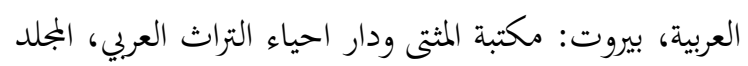

$$
\text { 3) فابة الإرب فن شرح لامية العرب }
$$

4) منطق الحاضر والبادى ومقصد الرايح

$$
\text { والغادى }
$$

5) فاية الايجاز في الحقيقة والمجاز 9

\section{ب) وصف المخطوطة}

مخطوطة عقد التوحيد فن تحقيق كلمة

التوحيد برقم 437 عربي 10 محفوظة في المكتبة

العامة بجاكرتا، وتوجد في فهرس المخطوطات العربية في تلك المكتبة. وهي إحدى مؤلفات عطاء الله بن أحمد بن عطاء الله بن أحمد المصرى الأزهرى الذى قد شرح فيه كلمة التوحيد شرحا واضحا.

خخطوطة عقد التوحيد يوجد منها

نسختان لنفس النص متساويتان كتبت بخط مختلف، المخطوطة الأولى مكتوبة بخط النسخ

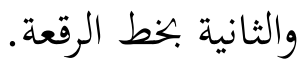

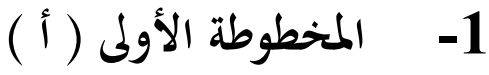

الصفحة الأولى ورد فيها عنوان التهان

المخطوطة وهو عقد التوحيد في تحقيق كلمة التوحيد واسم المؤلف وهو عطاء الله بن أحمد بن عطاء الله بن أحمد المصرى الأزهرى. ويذكر

$$
\text { 9مرجع السابق.، ص. - م. }
$$

${ }^{10}$ T.E. Behrend (ed); Katalog Induk Naskah-naskah Nusantara Perpustakaan Nasional RI; Jakarta : Yayasan Obor Indonesia \& Ecole Francaise D'extreme Orient, 1997; jilid 4. 
عنوان إحدى مؤلفاته تحت عنوان فتح العزيز الغفور بتحقيق تعلق القدرة بالمقدورة. بدأ النص بذابسم الله الرحمن الرحيم

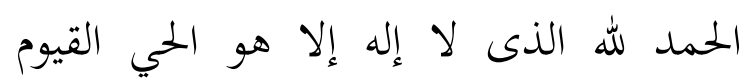

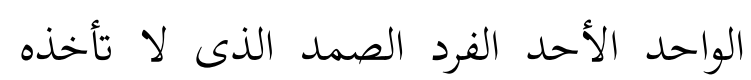
سنة ولا نوم والصلاة والسلام على من أرسله الله بالدين القويم وتوحيد الإله فبلغ رسالة ربه ولم تأخذه لومة لائم .......

رقم الصفحة مكتوب في لانماحية

اليمنى من الطرف الأعلى من الصفحات، ويبدو أها مكتوبة حديثا لأهنا مكتوبة بقلم الرصاص. تشمل المخطوطة 17 صفحة، وتشتمل كل صفحة على 23 سطرا، ماعدا الصفحة الحادية عشر تشمل 20 سطرا والصفحة الأخيرة تحتوى على 6 سطور، مكتوبة بكتابة عربية جميلة. ولا يوجد بالورق العلامة المائية أي ختم الورق watermark.

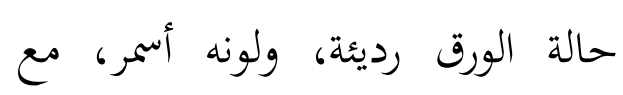
وجود الثقوب. وتاريخ تحرير النص فن الثامن والعشرين من شهر صفر سنة ثمانين ومائة وألف من الهجرة (1180 هـ). فن مطلع النص يذكر العنوان واسم المؤلف وهو عطاء الله

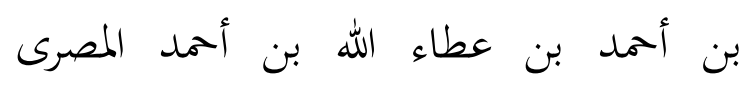
الأزهرى، ولا توجد بيانات عن اسم الناسخ ومحل تدوين المخطوطة.
ومقاس الأوراق 21 × 15,5 سم،

10,5 سم.

وحجم الكتابة 15 × ومعابر

وفى كل صفحة خطّ يحدد كتابة النص.

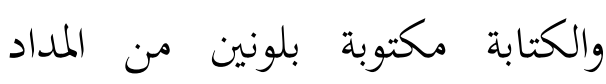

الأسود في غالب النص والحبر الأممر في بعض بلن من

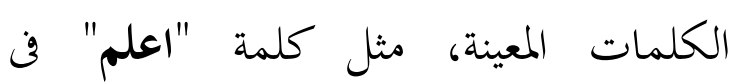
الصفحة الثانية وكلمة "الأول والثانى والثالث" في الصفحة الثانية أو الثالثة.

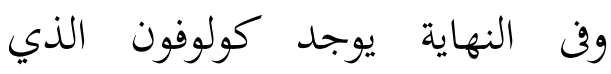
يكتب فيه تاريخ النسخ بشكل هرم مقلوب.

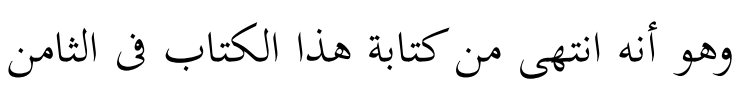
والعشرين من شهر صفر سنة 1180هـ على انى يد مؤلفها فقير عفو ربه الملك الأوحد عطاء الله بن أحمد بن عطاء الله بن أحمد غفر الله ذنوبه وأفاض عليه من الرضوان ويوفيه وغفر له

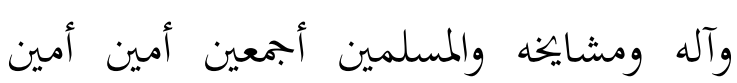
أمين.

\section{2- المخطوطة الثانية ( ب )}

الصفحة الأولى تشتمل على مقدمة

تدل على عنوان المخطوطة واسم المؤلف. ويذكر عنوان إحدى مؤلفاته تحت عنوان فتح العزيز الففور بتحقيق تعلق القدرة بالمقدورة، والكتابة متساويان بالمخطوطة الأولى. 
يختلف عدد السطور في الصفحة

الأخرى، ففى الصفحة الأولى تشمل على 20

سطرا والصفحة إلى بعدها تشمل على 21 ثم الثم الثم صفحة أخرى 25 سطرا والصفحة الأخيرة

12

ومقاس الأوراق 15,71 15 سم،

وحجم الكتابة 15,5×11 سم، وحمالة الة وراب المخطوطة رديئة مما يشكل صعوبة كبيرة

بالنسبة للباحثة بسبب صعوبة قراءة بعض ردئة الكلمات. فالكتابة غير واضحة والورق مملوء بالثقوب، والكتابة ممسوحة في بعض الأماكن. والكتابة مكتوبة بلونين أيضا من المداد الأسود والمداد الأحمر.

وبعد انتهاء النص توجد بعض بعض

الورقات التى بينت فيها النصائح والحكم وعلامة الإخلاص التى تؤدي إلى الخير لئي

ولتشجيع النفس في التقرب إلى الله كالتالى : قال وهب ابن أمنية رحم الله عليه مكتوب في التورية "من تزود في الدنيا صار حبيب الله، ومن ترك الغضب صار في جوار الله، ومن ترك حسن العين في الدنيا صار يوم

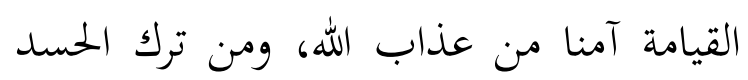
صار يوم القيامة محمودا على رؤوس الخلائق، ومن ترك حب الرياسة صار يوم القيامة عزيزا عند الملك الجبار، ومن ترك الفضول في الدنيا تروليا صار يوم القيامة امنا عما فن الأيد، ومن ترك تركي
الخصومة في الدنيا صار يوم القيامة من الفائزين، ومن ترك الضنة أي الفجل صار يوم القيامة مذكورا على رؤس الخلائق، ومن ترك ترك

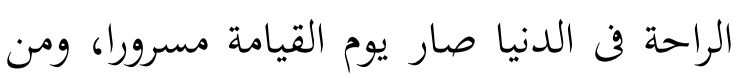
ترك الحرام في الدنيا صار يوم القيامة في جوار

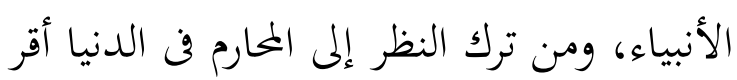
الله عينه يوم القيامة، ومن ترك الغناء في الدنيا

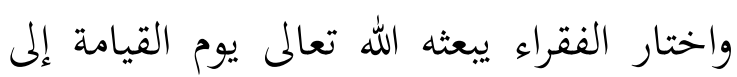
الجنة مع الأولين، ومن قام لحاجة اخيه المسلم في الدنيا قضى الله له حوائج الدنيا والآخرة،

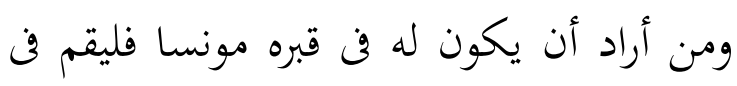

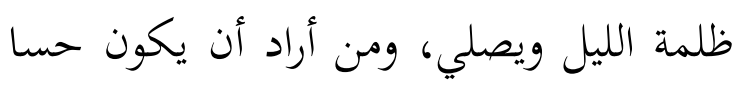

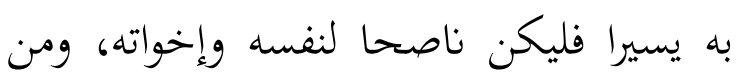
أراد أن يكون له زائرين فليكن ورعا، ومن أراد

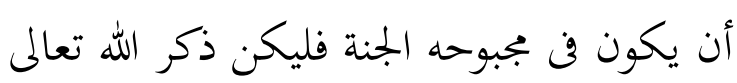
بالليل والنهار، ومن أراد أن يكون من يدخل فيلحن الجنة بغير حساب فليتب إلى توبة نصوحا، ومن أراد أن يكون غنيا فليكن رضا بما قسم الله تعالى له، ومن أراد أن يكون فقيها فليكن

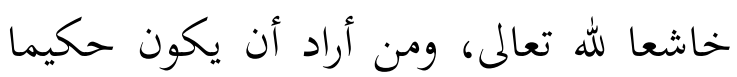
فليكن عالما، ومن أراد السلامة من الناس فلا يذكر أحدا إلا بخير ومن السلامة من طول امن المن القيامة بين يدي الله عز وجل فعليه باصمت إلا بخير، ومن أراد السلامة من الكبار والحيانة

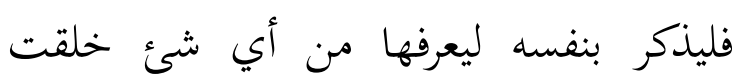

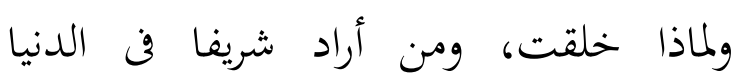


والآخرة فليختر الآخرة على الدنيا، ومن أراد

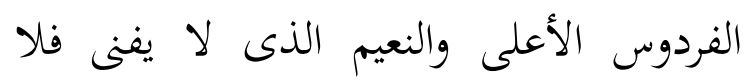
يضيع عمر وفن ضاد الدنيا، ومن أراد الحاجة

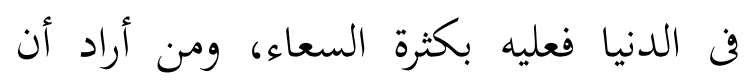
يكون عزيزا في الدنيا والآخرة فعليه بالسخافان السخي قرب من الله وقرب من الرجمة وبعيد من النار، ومن أراد أن ينور الله قلبه بالنور التام

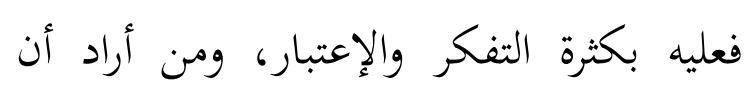
يكون له بدن صابر ولسان ذاكر وقلب خاشع فعليه بكثرة الإستغفار والإستعانة للمؤمنين والمؤمنات ومنبهات من لم يصبر على صحبة

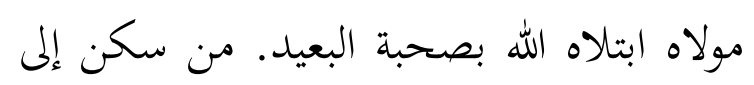
غير الله بسره نزع الله تعالى الرجمة من قلوبهم عليه وألبسه لباس الطمع فيهم أي الإخلاص. ومن لزم عدم المخالفة والعصيان إذ حقيقة المعصية بقاء مع الاكوان من النفس والهوى والشيطان ومن خرج من هذه الأشياء كلها كيف يخلق ما أمره به الرحمن."

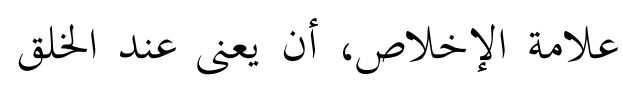

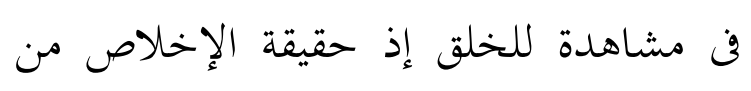
شهود الاكوان والدخول فن مقام الاحسان حتى لو شهد في إخلاصه الإخلاص احتاج إخلاصه إلى الإخلاص إذ الإخلاص أيضا من

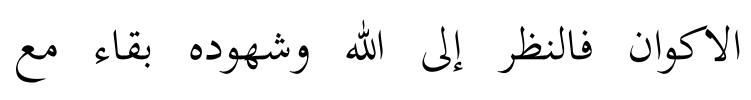
الاكوان فلذلك كان الإخلاص قليل المثال لا ينال قيمة منه إلا المكمل من الرجال.
وقد اخترت المخطوطة الأولى ( ) )

لأنها واضحة ولسهولة قراءة النص، لتكون بحثا للدراسة الفيلولوجية. النص مع التحقيق أ- نص عقد التوحيد في تحقيق كلمة التوحيد

بسم الله الرحن الرحيم الحمد لله لله

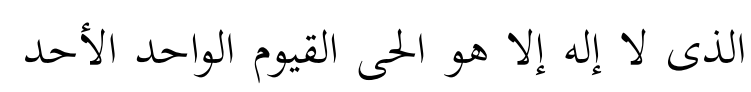

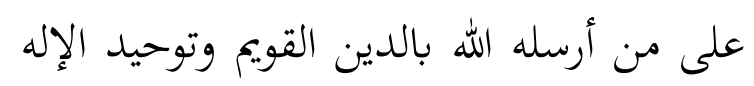
فبلغ رسالة ربه ولم تأحذه لومة لائم فن الله وعلى آله الحائزين قصب السبق في مضمار العرفان وأصحابه الذابين عف دين الله كل ذي الهين بغي وطغيان 11 ماوحد الله في كماله موحد الندابين وحاد عن طريق الحق كل ملحد وبعد. فهذه وطنيان رسالة لطيفة وفائدة شريفة لقبتها بعقد التوحيد

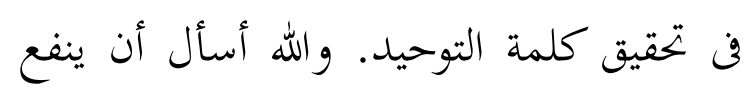
ها الطالبين وأن يوجد إليها رغبة الراغبين 12 أنه أكرم مسؤل وأعظم مأمول 13.

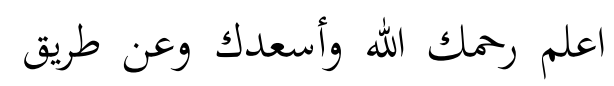
الضلال جنبك وأبعدك أفم أوردوا أشكالا على الإستثناء حاصله أن كل إستثناء يتضمن الجمع بين النفى والإثبات عن حكم المستثنى، مثلا إذا قلب له علىّ عشرة إلا ثلاثة فقد الند

$$
13 \text { 13 فن النص النص مكتوب : طفيان النص مكتوب : الراشبين : ماءمول }
$$


أثبت الحكم لا ثلاثة أوّلا في ضمن المستثنى منه ونفيه عنها ثانيا صريحا وهو تناقض باطل، وأجيب عنه بأجوبة منها وهو أطردها ولذا اقتصر عليه إبن الحاجب في مختصر المنتهى أنه يعتبر الإستثنا والإخراج من مدلول المستثنى منه

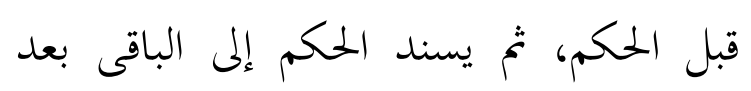
الثنيا فلا يكون هناك إلا حكم واحد فلا تناقض، ومنها أن السبعة لما إسمان مفرد، وهو لفظ سبعة ومركب وهو لفظ عشرة إلا ثلاثة، ومنا

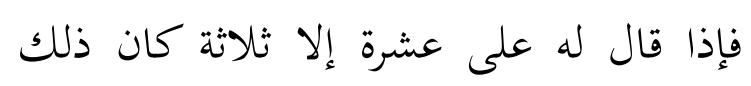
بمنزلة قوله له على سبعة، فلا يكون هناك إلا

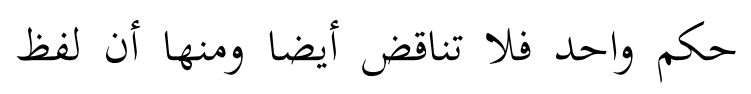

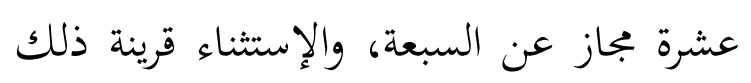
المجاز الذى هو من قبيل استعمال اسم الكل في الجزء فلا يكون هناك إلا حكم واحد فلا

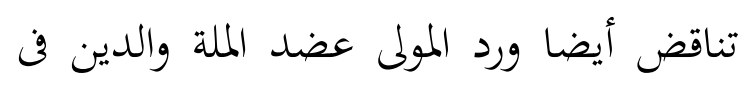
شرحه على يختصر المنتهى تلك الأجوبة بأسرها بأها ينافيها قول الإستثناء من النفي

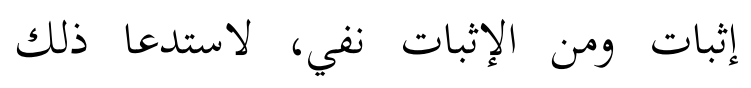
وجود حكمين مختلفين بالإيجاب والسلب في إلبات جانب المستننى، فالتناقض محقق والأشكال باق بحاله. وقد عنّ لي جواب حين إقواءي للشرح المذكور الفطر في البحث المزبور مصله لئل أن إسناد الحكم إلى المستثنى في ضمن المستثنى منه حاصل غير مقصود حفظا لقاعدة الإستثناء وهى الإخراج من متعدد أى من
حكمه والخروج إنما يكون بعد الدخول وإسناد

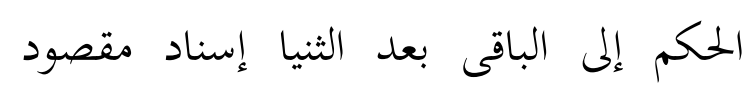

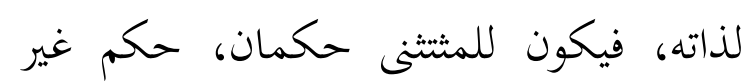

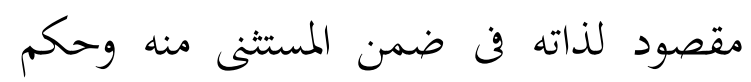
مقصود لذاته ثبت له صريحا والتناقض إنما يقعد 14 بين حكمين مقصودين لذاتم. لفئ. فان قلت "يلزم عليه أن يكون إسناد واحد مقصودا لذاته وغير مقصود لذاته وهو

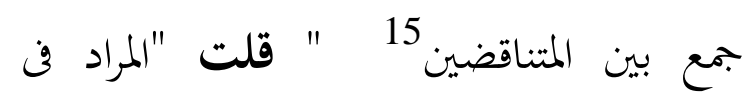
الإسناد إلى الأمور المتعددة نوعه لاشخصه ولايضر وصف الأمر الكلي بالمتقابلات كالإنسان يوصف بالكتابة باعتبار تحقق في وصن

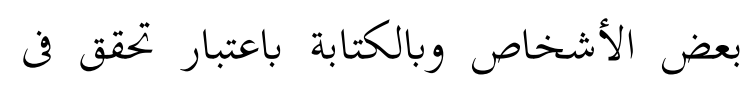
ضمن بعض أضر منها، ولذا قال علماء 16 العربية إن المسند في نحو قولك "جاء زيد

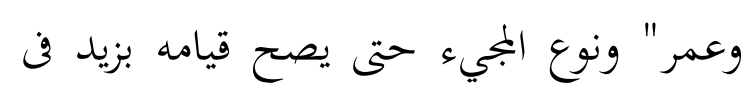

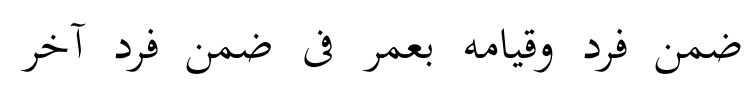

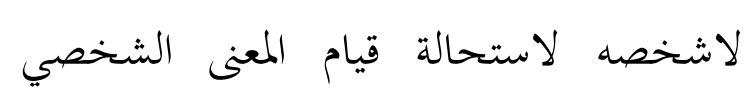

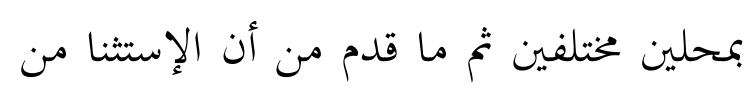
النفي إثبات ومن الإثبات نفي، هو ماذهب إليه الشافعى 17 وذهب أبو حنيفة 18 إلى أن النبات نفي، ماذب

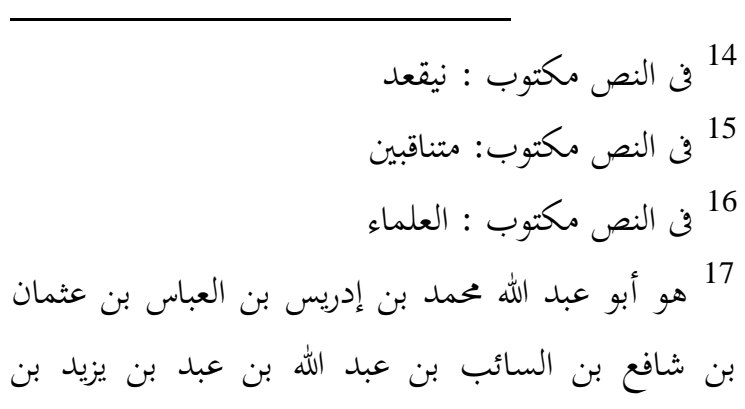


الإستثناء من الإثبات نفي، والمستثنى بعد النفي سكوت عنه غير 19 متعرض له له بهكم الإنبات أصلا وأورد عليه أن يلزمه أن لا يكون كلمة

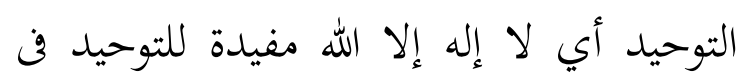

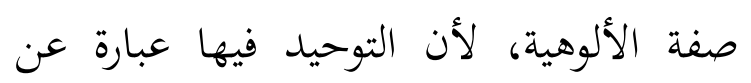
إثبات صفة الألوهية لله ونفيها عما عداه من الأن العقلاء وغيرهم. وأجيب بأها تفيد التوحيد

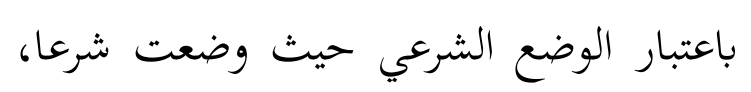
لذلك وإن لم تفده بحسب وضع اللغة وثانيا بأن ثبوت صفة الألوهية لله تعالى أمر متفق وضق الفقان

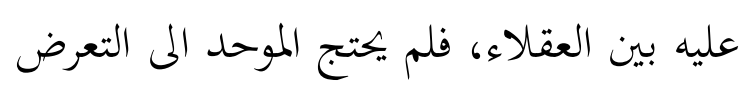
له ونفي صفة الالوهية عن غير الله تعالى

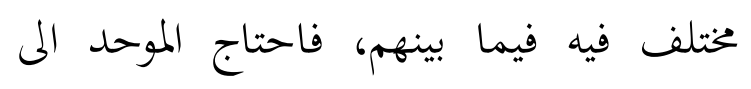

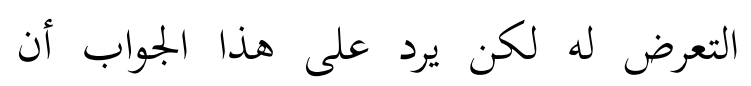

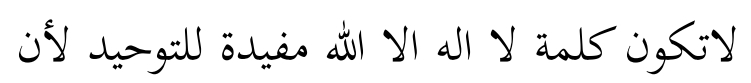
التوحيد عبارة عن مجموع الحكمين السلبي

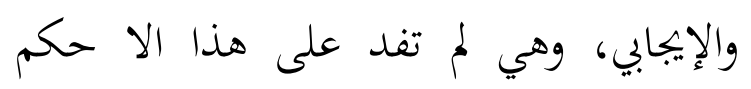
السلب فقط مع أها كلمة توحيد بالإجماع، ويمكن أن يجاب عن هذا إلا يراد باها كلمة

المطلب بن عبد مناف بن قصي القرشي المطلّبي الشافعي

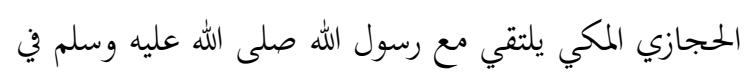

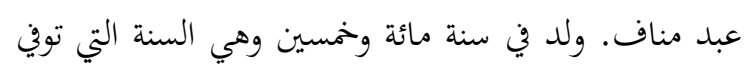

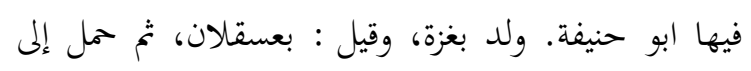
مكة وهو ابن سنتين. 18 ابو حنيفة هو النعمان بن ثابت بن النعمان بن زورط

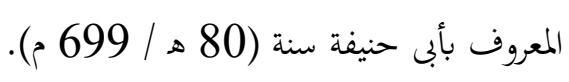

$$
\begin{aligned}
& 19 \text { في النص مكتوب : غان حنغ }
\end{aligned}
$$

توحيد باعتبار إفادتما أعظم حكميّة غايته أن نسبة التوحيد إليها مجازية وتسمية أعظم الحكمين توحيدا بجاز من باب إطلاق اسم إسبه الكل على أعظم أجزائية، نحو قوله صلى الله به بله عليه وسلم (الحج عرفة من جاء ليلة جمع قبل المجل طلوع الفجر فقد أدرك الحج أيام منى ثلاثة فمن تعجل فن يومين فلا إثم عليه ومن تأخر

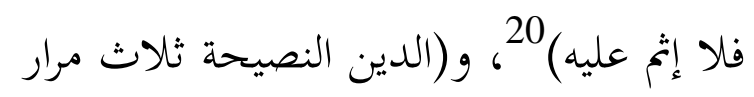
قالوا يارسول الله لمن قال لله ولكتابه ولأئمة المسلمين وعامتهم)212، وكتسميتهم ربيئة القوم عينا، وذلك كثر في الكلام البليغ. ثم اعلم أن كل قضية حملية تشتمل على عقدين عقد الوضع وعقد الحمل، أما

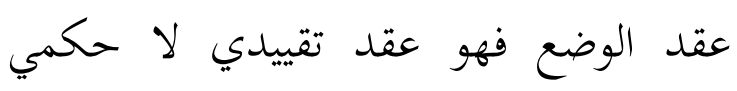

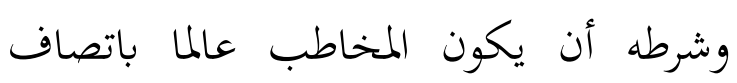
ذات الموضوع بالوصف العنواني بالفعل، كما ذهب إليه ابن سينا22 أو بالإمكان 23 كما المواي بالفعل كما

20 حديث أخرجه التزمذى (814)، في الباب : ما جاء

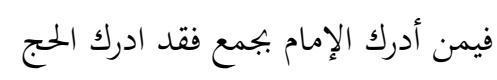

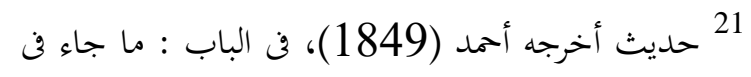
النصيحة 22 ابن سينا هو أبو علي الحسين بن عبد الله بن الحسن بن

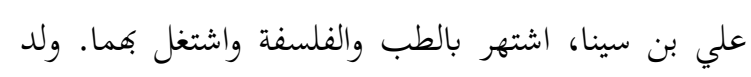
في قرية (أفشنة) الفارسية قرب بخارى (في أوزبكستان حاليا) من أب من مدينة بلخ (في أفغانستان حاليا) و أم قروية

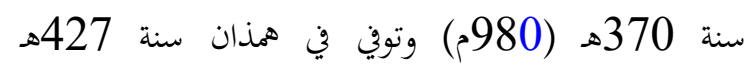
(1037م). عرف باسم الشيخ الرئيس وسماه الغربيون بأمير هون 
ذهب اليه الفارابي 24، وأما العقد الحمل الذى هو مناط الحكم فهو عقد إخباري وشرطه أن أن النها

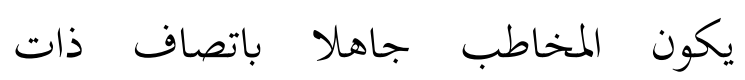
الموضوع بالوصف الحملي لأنه محط الفائدة25 وموضع الإثبات والنفي ومرجع التصديق

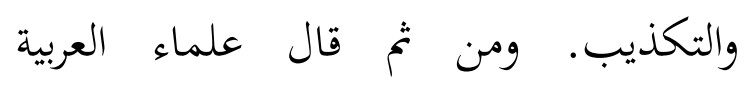
الأوصاف قبل العلم بها إخبار والإخبار بعد العلم بها أوصاف، فأي الوصفين علم المخاطب اتصاف ذات الموضوع به ينبغي ان ان المنين يقوم اللفظ الدال عليه ويجعل موضوعا ومحكوما عليه وأي الوصفين جهل المخاطب لئبل

الأطباء. وقد ألّف 450 كتاب في مواضيع مختلفة، العديد

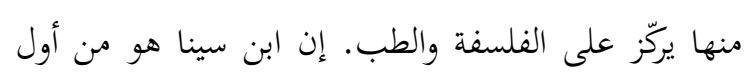

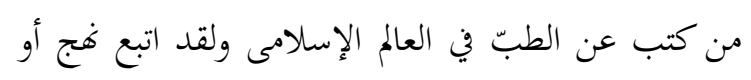

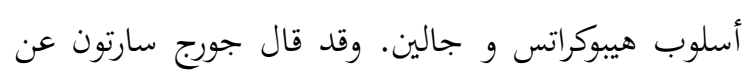

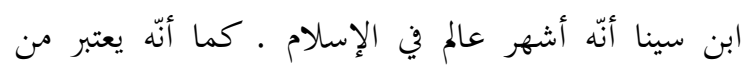

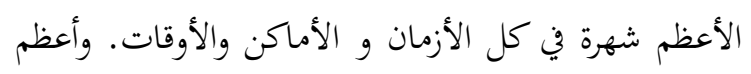

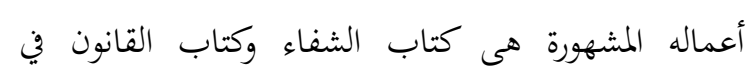

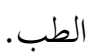
23 في النص مكتوب : الأمكان

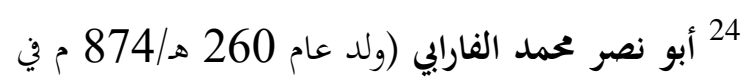

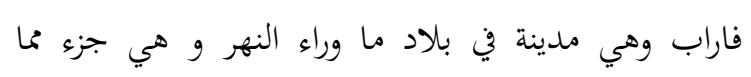

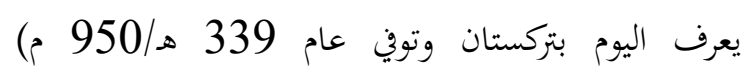
فيلسوف أتقن العلوم الحكمية، وبرع في العلوم الرياضية،

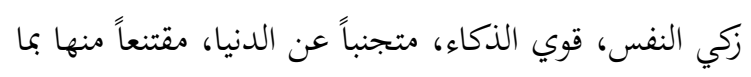

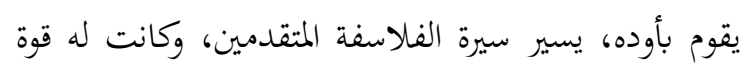

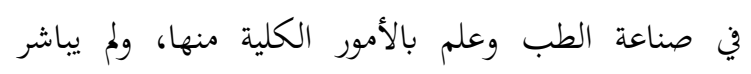

$$
25 \text { فم النصا، ولا حكتوب : ازئياتا. }
$$

اتصاف الذات به ينبغي أن يؤخر اللفظ الدال

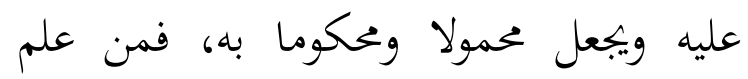
تسمية شخص باسم زيد واتصافه يكون مسمي بهذا الإسم وجهل اتصافه بكونه أخاه

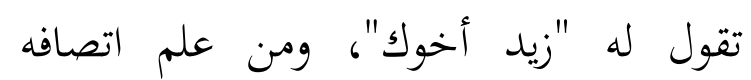
شخص بكونه أخاه وجهل اتصاف يكون مسمى باسم زيد تقول له "أخوك زيد" ويقول

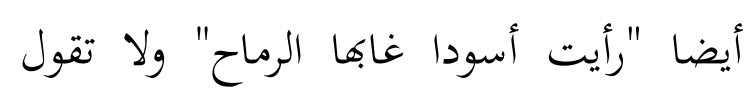
"رماحها الغاب" لأنه يخاطب به من علم أن ران

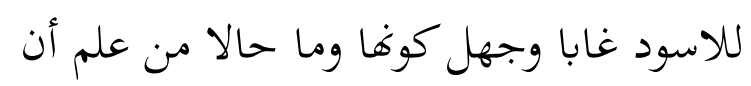
الأسود رماحا وجهل كوغا غابا وهو ظاهر. فان قلت "كيف هذا مع ماجوزه علماء العربية من كون المبتدأ والخبر معرفة نخو زيد أخوك وعمر وهو الصديق والتعريف إشارة

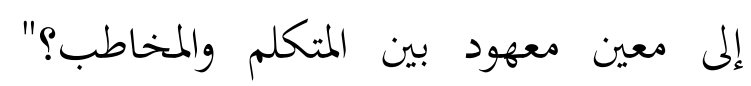
قلت معرفة الخبر باعتبار ذاته لا ينافى الجهل به باعتبار أنشابه الى ذات المبتدأ. ثم اعلم أن النفي والإثبات لاتوجهان إلى نفس الذوات ولا إلى نفس الصفات وإنما يتوجهان إلى نسب الصفات إلى الذوات وذلك لأفما من عوارض النسب كالضرورة

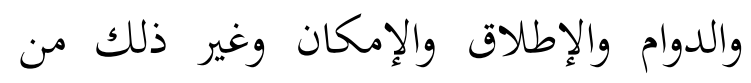

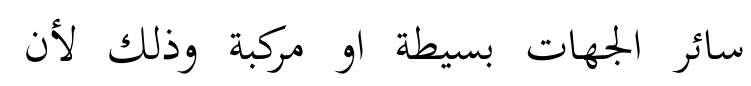
الإيجاب عبارة عن إيقاع النسبة والسلب عبارة عن انتزاعها. 
ثم اعلم أن القصر على أربعة

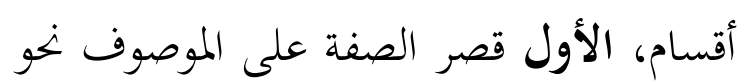
ما علم إلا زيد، والثالي قصر الموصوف على

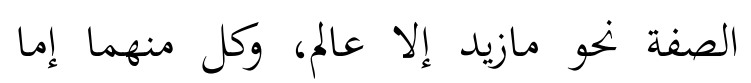

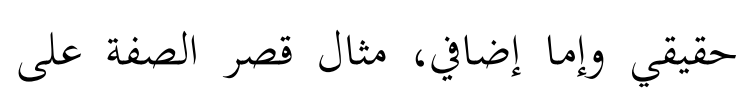

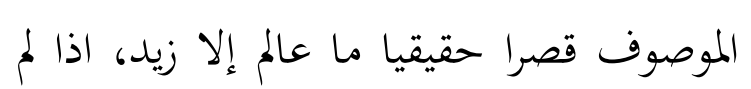

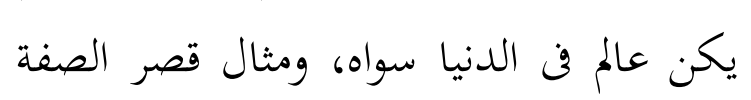

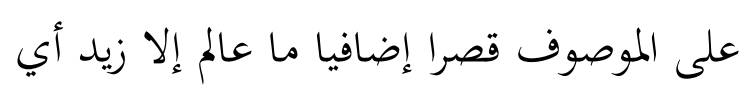

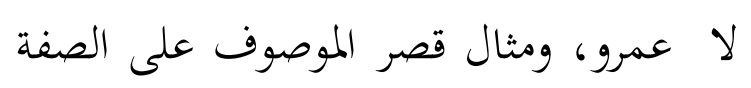

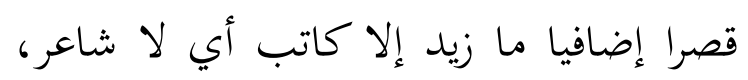
وأما قصر الموصوف على الصفة قصرا حقيقيا فمتعذر لتعذر الإحاطة بجميع أوصاف الشئ

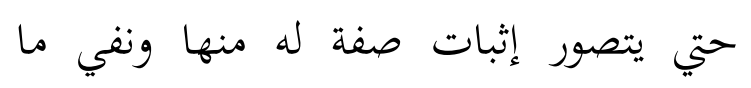
عداها عنه بل حكموا باستحالته لأن من جملة الصفات أيضا، فيلزم رفع النقيضين وهو محال

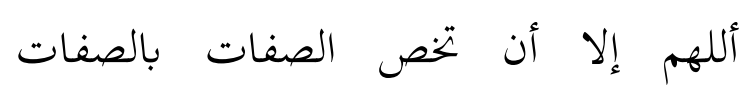
الوجودية حتي لايستلزم ذلك القصر رفع النقيضين المحال. ثم للقصر طرق أربعة، أولها النفي والإستثنا كما هنا والواقع بعد النفي هو النيال

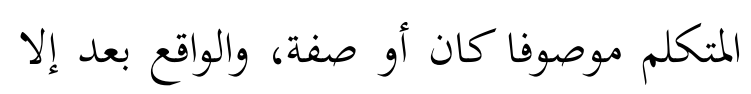
هو المقصور عليه كذلك وثانيها إنما وتاليها هو المقصور موصوفا كان أو صفة، وتالي تاليها هو المقصور عليه كذلك، وثالثها العطف بلا النافية، ثم إن كان المعطوف صفة

$$
26 \text { في النص مكتوب : الربعة }
$$

نحو زيد كاتب لا شاعر فهو قصر موصوف علي صفة، وإن كان المعطوف موصوفا نحو زيد كاتب لا عمر فهو قصر صفة على فالى موصوف، ورابعها تقديم ما حقه التأخير، نغو تميمي أنا ومؤخرها 27 هو المقصور، والمقدم هو نوريم المقصور عليه أي أنا مقصور على تميمية

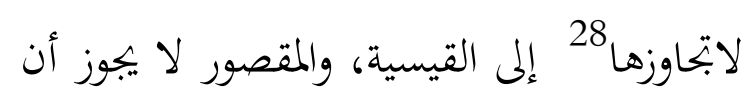
يتعدي المقصور عليه إلى ماعتبر مقابلا له في لهابه الحكم به أو عليه والمقصور عليه يجيجوز أن يتعدي المقصور إلى غيره موصوفا كان كل منهما أو صفة. ثم اعلم أن الله علم شخصيا29 ذات البارى تعالى في الواجب الوجود

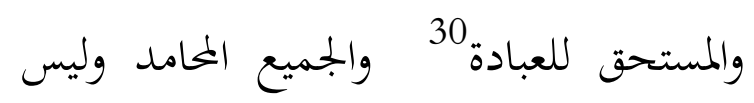
إسما لمفهوم الواجب أو المستحق للعبادة حتي

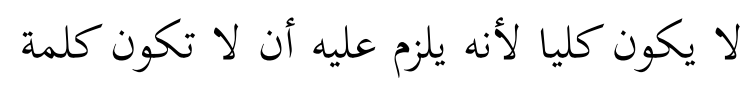

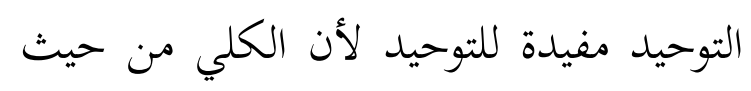
هو كلي يحتمل الكثرة المنافية للوحدة مع أها

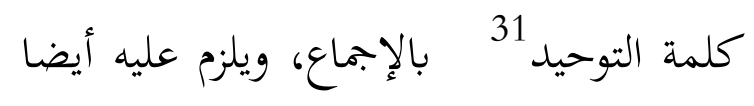
إما إستثناء الشئ من نفسه ان أريد من إله

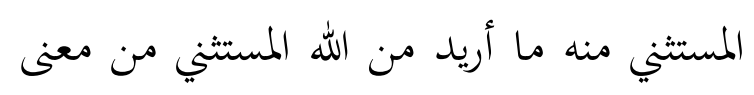

$$
\begin{aligned}
& 27 \text { في النص مكتوب : والمؤخرها } \\
& 28 \text { في النص مكتوب : لااتحاوزها } \\
& 29 \text { في النص مكتوب : شخصي } \\
& \text { 30 في النص مكتوب : للعباده } \\
& 31 \text { في النص مكتوب : توحيد }
\end{aligned}
$$


هذه 35 المقدمات وتقدمت تلك التمهيدات، واجب الوجود أو المستحق للعبادة أو من

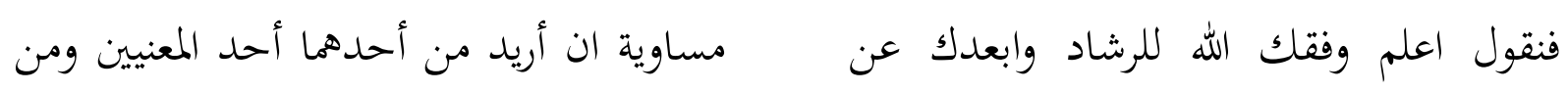

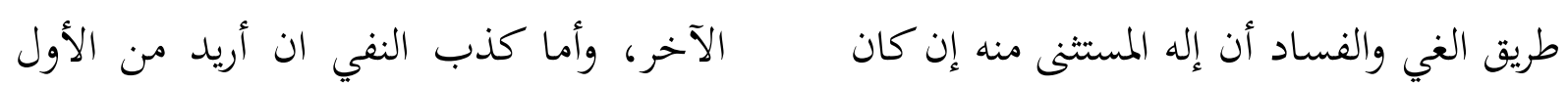

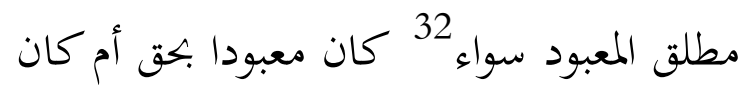

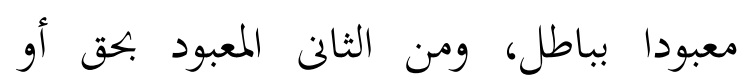
واجب الوجود لوجود المعبودات الباطلة بكثرة فلا يصدق سلب الوجود عنهما كذا قروه العلامة التفتازانى وهو مبني على أن الحكم المنفي في جانب المستثنى منه والمثبت في جانب المستثنى هو وصف الوجود دون وصف الألوهية بل هو وصف عنوان وقيد للذات

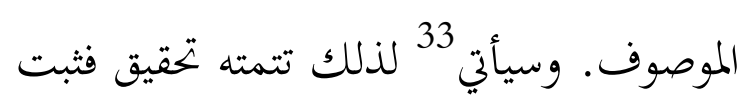
أن الإله يطلق على ثلاثة معان على المطلق

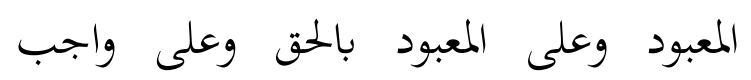
الوجود وأما إطلاق على من بتجب طاعته من أمير أو والد أو سيد فلم يرد فن اللغة وإطلاقه على ذلك حرام كإطلاقه على الأصنام إلا مقيدا بالبطلان كقولك هذا إله 34 باطل أو الألى إلى مضافا إلى من كان يعبدها كان تقول "كانت إلهة مشركي قريش اللات العزى ومناة وغير ذلك أو على جهة الأفكار ونحو أإله مع الله؟ أفرأيت من التخ الهه هواه؟". اذا تمهدت

$$
\begin{aligned}
& 32 \text { في النص مكتوب : سوا } \\
& 33 \text { في النص مكتوب : سباءتى فئن } \\
& 34 \text { في النص مكتوب : له هـوب : سباء }
\end{aligned}
$$
إسماء مشتقا من إله اذا عبد فهو صفة،

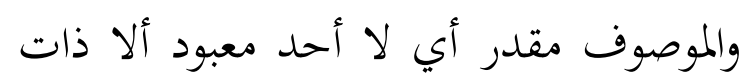

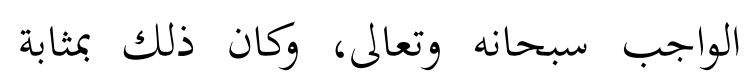
قولك "لا شاعر إلا زيد" فحذفت الموصوف ونسال وهان وأقيمت صفته مقامه فبنيت على الفتح فيكون

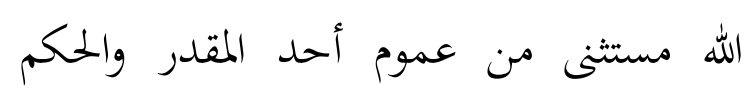
بوصف الألوهية بمعنى وجوب الوجود أو احن

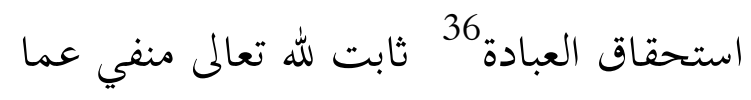
عداه. والقصر على هذا من باب قصر الصفة على الموصوف قصرا حقيقيا وقد تقدم إشارة إلى ذلك وان كان إسما جامدا كان مبتداء محذوف الخبر، والخبر المقدر موصوف بجميع صفات الكمال التى من جملتها وجوب الوجود وامتناع الشريك والعلم الشامل والقدرة الكاملة وغير ذلك من بقية الصفات الكمالية ثبوتية كانت أو سلبية، والمعنى لا أحد مما يطلق عليه أمم الإله موصوف بجميع صفات الكمال إلا الله تعالى الذى ليس كمثله شئ، وكان ذلك الإله موصو

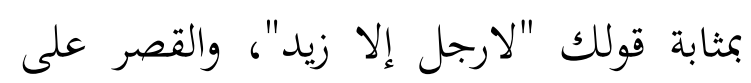
هذا أيضا من قبيل قصر الصفة على الموصوف

$$
35 \text { ف3 في النص مكتوب : هذا }
$$


قصرا حقيقيا، ويبجوز أن يقدر الخبر واجب

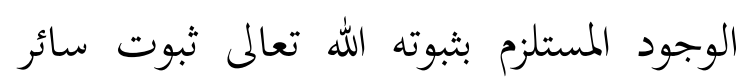

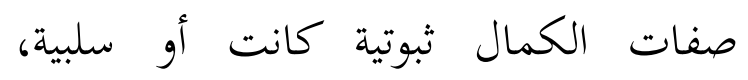
فيحصل مقصود الموحد من إثبات الوجود لئل الواجب له تعالى وامتناع وجود الشريك لأهنا ترجع إليه استلزام وذلك لأنه يلزم من كونه واجب الوجود كونه عالما إذ لو كان جاهلا لكان جائز الوجود العروض خلافه وهكذا يقال بها في الصفات، فوصف الوجود منبع كل كمال ومنبع كل إفضال، ولذا أختير بيانا للذات العلية في قولمم "و الله علم على الذات الواجب الوجود" بل كل وصف كمالي لله تعالى أخذ يحجزه باقي الأوصاف ويرجع إلى الى وحفد كل وصف على خياله باقي الأوصاف بنوع استلزام أيضا فصغاته تعالى مثلا ذمة. فان قلت "يلزم أن يكون مثل قولنا لا عالم إلا الله او قادر إلا الله مفيدا للتوحيد وهو باطل"، قلت "قد تعبدنا الله تعالى في شأن التوحيد بلفظ لا إله إلا الله خصوصا فلا يقوم غير مقامه وأن أدى معناه، ونظير ذلك إلك إلك تكبيرة الإحرام أي الله أكبر حيث تعبد الديدان

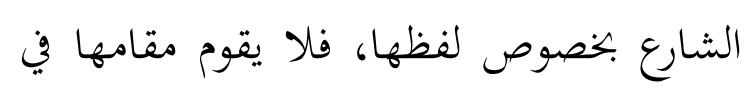

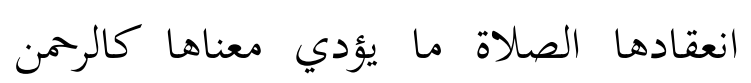
أكبر أو الله كبير أو عظيم كما ذهب إلعاد ماليه
إمامنا الشافعي 37 رضي الله تعالى عنه وإما تقدير الخبر والحالة هذه موجود فيرد عليه أنه لايلزم من كونه موجودا كونه واجب الوجود

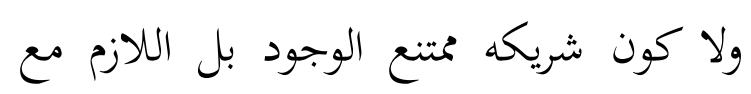
ذلك كون شريكه غير موجود، والعام لا يستلزم الخاص مع أن التوحيد لا يتحقق إلا بالحكمين، أعني الحلكم عليه تعالى بكونه

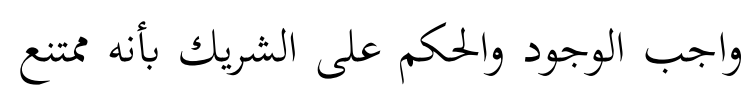

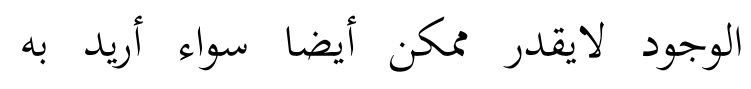
الإمكان الخاص أي سلب الضرورة ان جانبي

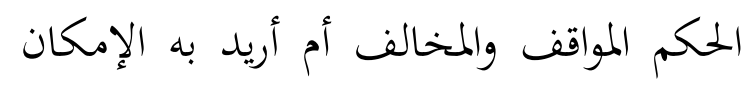

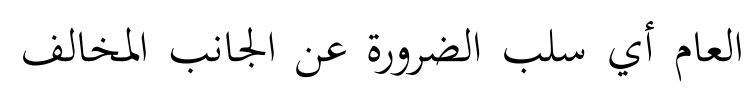

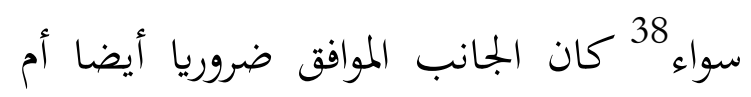
لا، لأنه أعم من الإمكان الخاص فيصدق به

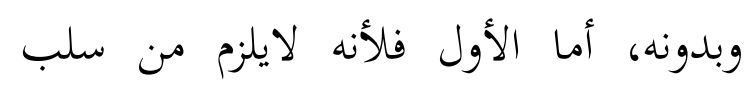

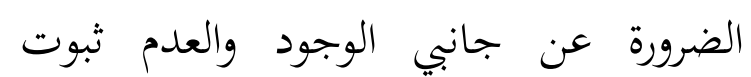
الضرورة في جانب الوجود لله تعالى فضلا عن ثبوت وجوب الوجود له تعالى ولا ثبوت العدم

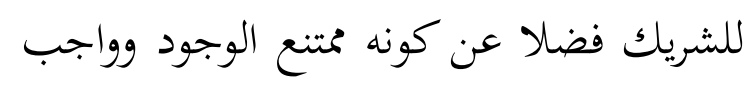
العدم ففساده من وجهين، وأما الثانى فلأنه لا لاجن يلزم من سلب الضرورة عن جانب العدم ثبوت الضرورة في جانب الوجود الله تعالى أم لا يجيوز أن تسلب الضرورة من جانب الوجود

$$
37 \text { الشافعى هو كما ذكر في السابق النص مكتوب : سوا }
$$


أيضا، فيتحقق الإمكان العام في ضمن الإمكان الخاص، وان لزم منه الضرورة عدم الشريك وهو غير كاف في أمر التوحيد كما مر، ففساده من وجود واحد لايلزم من سلب الضرورة عن جانب الوجود بثبوت الضرورة في وني جانب العدم للشريك وان لزم منه ثبوت بن الضرورة في جانب الوجود لله تعالى، ففساده كالذي قبله وكل ذلك لا يخفى على المرقاض

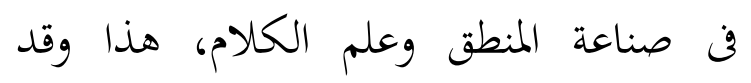
ذهب بعض علماء العربية إلى أنه لا حذف ولف في مثل هذه الكلمة وان الأصل الله-إله أي الي اله لهاء واجب الوجود أو مستحق لجميع العبادات، فلما قصد الموجد تخصيصه بصفة الألوهية قدم الخبر على المبتدأ وادخل النفي على الخبر وأداة

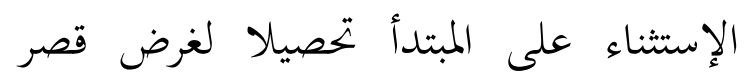

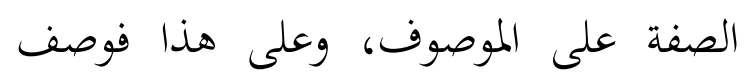
الألوهية وصف حملي لا وصف عنواني، لكن كلام البيانين يقتضي الحذف فن مثل ذلك كما صرح به السكاكي في المفتاح والخطيب في التلخيص وغيرهما.

تنبيه قد علمت من قولنا أن النفي والإثبات لا يتوجهان على نفس الذوات ولا على نفس الصفات، بل مورده نسبة الصفات إلى الذوات بطلان قول من قال أن المقصود من كلمة التوحيد نفي كل ذات موصوفة وإثبات ذات واحدة موصوفة بها اللهم إلا أن
يحمل على تقدير مضاف أي نفي صفة كل ذات موصوفة بالألوهية وإثبات صفة ذات واحدة موصوفة بها وبعد ذلك فالكلام لا يخلو

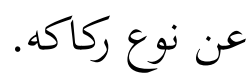
فان قلت "لم أختير في التوحيد تقديم النفي على الإثبات ولم يمكن فقيل لا إله إلا الله ولم يقل الله اله لا غيره،" قلت "التخلية مقدمة على التحلية طبعا فقدمت عليها وضعا ليوافق الوضع الطبع." مانع التحله طبعا فان قلت "فما جهة قضية كلمة التوحيد؟" قلت "جمعتها لإطلاق العام أعني ثبوت المحمول للوصف ونفيه عنه بالفعل

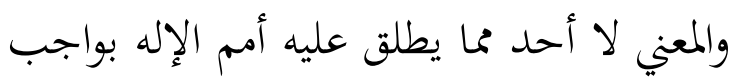
الوجود اوبمتصف بجميع صفات لاحلم الكمال بالفعل إلا لله، فإنه كذلك بالفعل والإطلاق

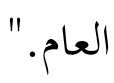
فان قلت "كيف يكون العامي الذى لايدرك مثل هذه التحقيقات موحدا بتلك الكلمة؟" قلت "يفد مواحدا باعتبار فهم معناها إجمالا والإيمان كما تفصليا يكون إجماليا، وإن كان الأول أكمل من الثانى على أن فوق هذه التحقيقات تحقيقات آخر، بعضها أرفع من بعض وفوق كل ذي علم عليم حتي ينتهى الأمر إلى الله تعالى." 
تنبيه الألوهية كما علمت تطلق تارة

على صفة وجوب الوجود وتارة على صفة استحقاق 39 العبادة 40 والتوحيد باعتقاد نفي وجني الشركه في كل من الصفتين، والإشراك باعتقاد الشركة في أحد الوصفين بأن يعتقد أن الله ولهن شريكا في صفة وجوب الوجود، كما وقع " للمجوس 41 أو يعتقد أن الله شريكا في صفة الوجدة كما وفع استحقاق العبادة، كما وقع لعبده الأصنام، وعلى هذا فالقصر قصر إفراد يخاطب من يعتقد الشركة في الحكم، وإما ما وقع للمعتزلة من إثبات شركا لا يخص في الخالقية لله تعالى حيث زعموا أن العبد يخلق أفعاله الاختيارية

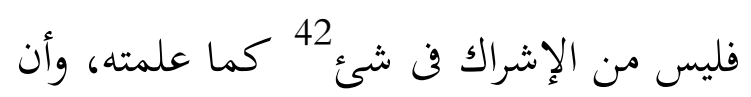

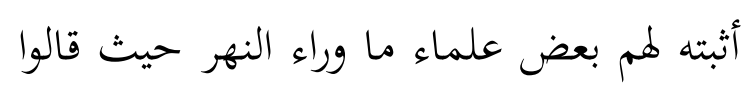
إن المجوس اسعد حالا منهم لأفم أثبتوا لله

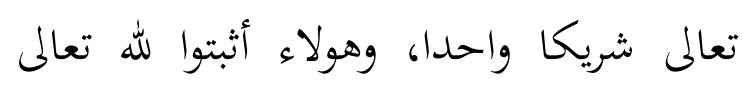

$$
39 \text { في النص مكتوب : استحقا }
$$

41 4الزرادشتية (أو المجوسية) ديانة أسّسها زرادشت : العبارة

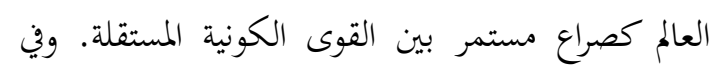

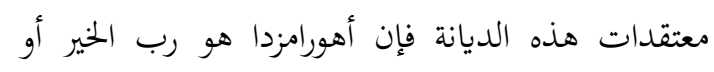

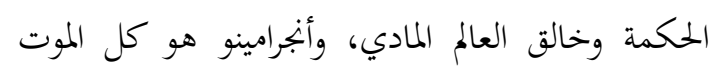

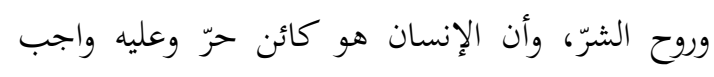

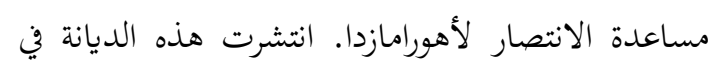

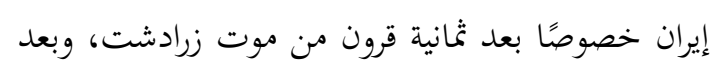

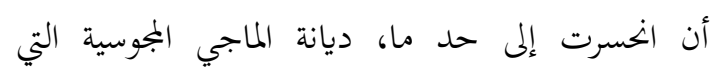
اقتصرت حينها على الملوك والكهنة.

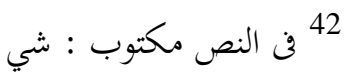

شركا لا تحصي بل ليس هذا من باب إثبات

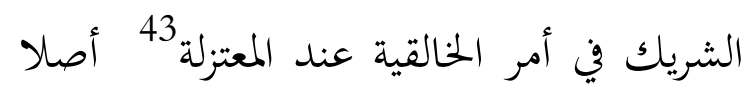

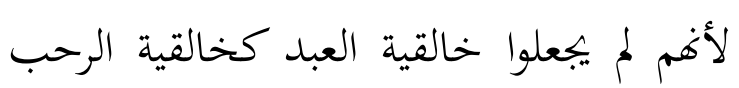

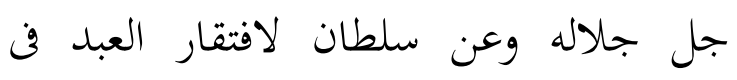

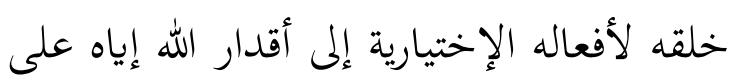
ذلك الفعل بخلقه تعالى الإرادة والقدرة

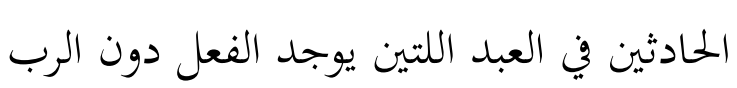

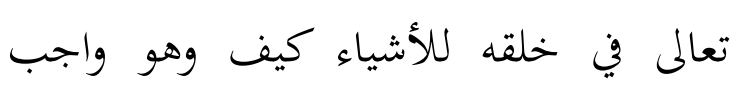
الوجود الغني عما عداه المفتتر إليه كل ماسواه اللهم اغننابك عمن سواك من سائر المخلوقين أمين أمين أمين يارب العلمين.

تتمهد في إعراب كلمة التوحيد لا لا نافية للجنس أي لنسبة صفته وحكمه إليه، إله

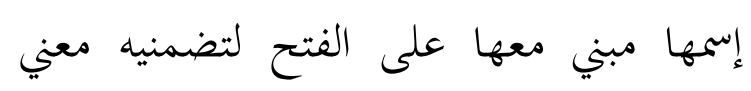
الحرف وهو من الاستغراقية اله الأصل لا من الطن

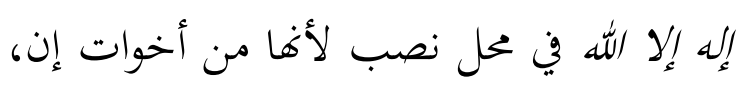

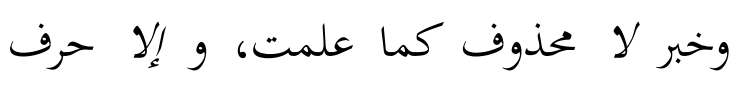

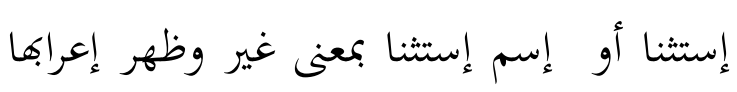

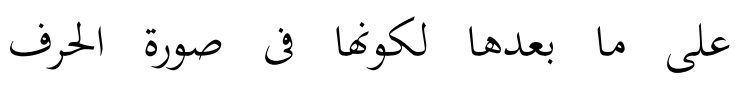

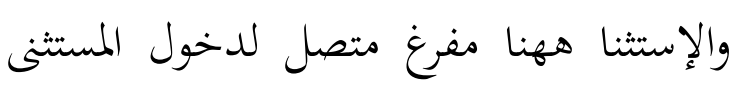

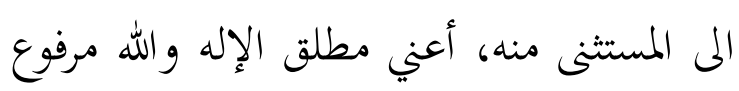
على أنه يدل من الضمير في خبر لا المخذوف، المئه

30 المعتزلة هى فرقة كلامية ظهرت في بداية القرن الثاني

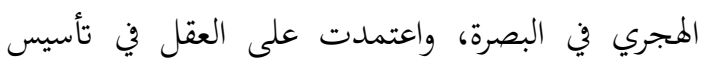
عقائدها، وهذه الفرقة تقول بأنّ العقل والفطرة السليمة قادران على تمييز الحلال من الحرام بشكل تلقائي 
وقيل وهو بعيد أنه يدل من محل إسم لا قبل دخول الناسخ وهم تارة يتبعون على المحل الغريب وتارة يتبعون على الملل البعيد كما تقرر

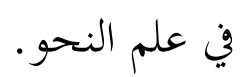

خاتمه التوحيد على ثلاثة أقسام أولها توحيد العوام وهو عبارة عن إثبات الألوهية لله بعد نفيها عما عداه على ماهو مدلول كلمة

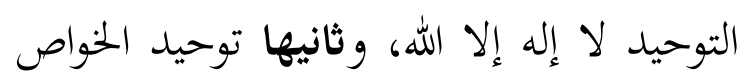

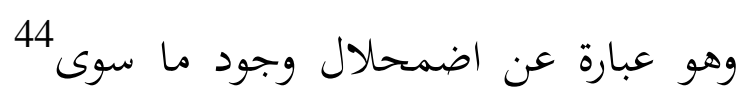
الله تعالي من الكائنات بحيث لا يشاهد بقلبه إلا وجود الله وحده كما لا يشاهد في النهار

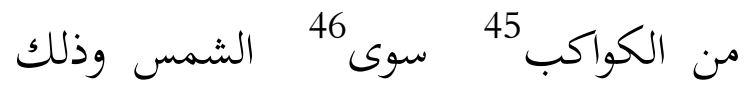
لأنه لما استولي علي قلوب عباد الله المقبولين محبة الله تعالى انقطعت عقولم عما سواه وذهلت عما عداه فلم يسبق لمم شعور بالعلوم

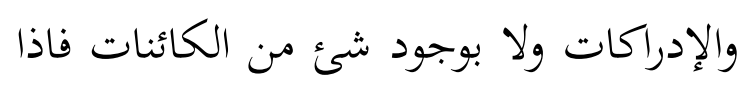
اضمحل وجود ما سوى الله تعالى كان الله

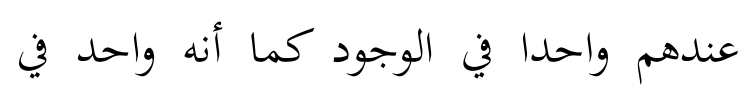
الألوهية، وثالثها توحيد أخص الخواص الخداص وهو أنه واحد في نفي الوجود حقيقة عما سوى الله تعلي وإثباته له تعالي وحده وذلك بأن يراه ذاتا موجودا خارجيا واحدا شخصيا وما سواه أمور عدمية ظهرت في الحس بسبب إشراق نوره وجوده

$$
\begin{aligned}
& 44 \text { فن النص مكتوب : سو } \\
& 45 \text { في النص مكتوب : كواب } \\
& 46 \text { في النص مكتوب : سواي }
\end{aligned}
$$

تعالي عليها ونعلقه بها كنور الأجرام المفاض

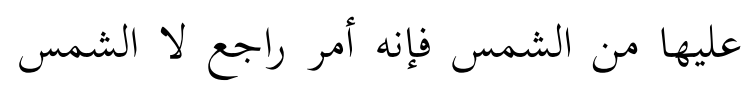
حقيقة واكتساء الأجرام به إنما هو على طريق لإن الفيق العادية المسترجعة فسبحان من عزله الوجود لذاته ولغيره العدم لذاته والوجود لغيره. وقد تحررت هذه القواعد وتقررت هاتيك الفوايد

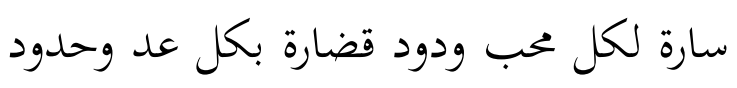
علي يد مؤلفها فقير عفو ربه الملك الأوحد عطاء الله بن أحمد بن عطاء الله بن أممد

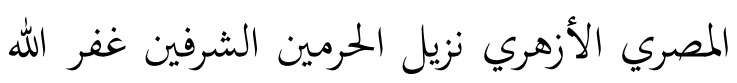

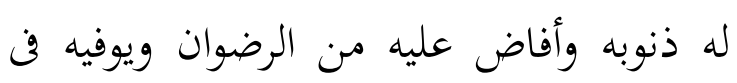
يوم الثلاثا المبارك خامس عشر شهر ربيع لئه الثاني من شهور سنة ألف ومائة وتسعة

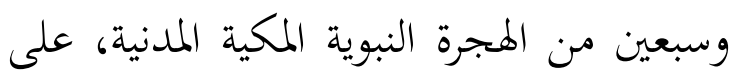
ربها من ربه فضل الصلاة وأكمل التحية وآله السادة الطاهرين وأصحابه القادة الأكرمين

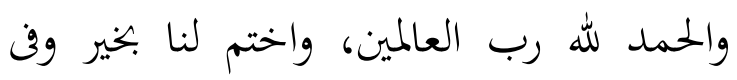
خير واجعل أمورنا كلها إلى خير أمين أمين أمين. بسم الله الرمن الرحيم، نحمدك يا من

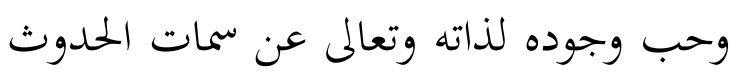
في صفاته ونصلي ونسلم على سيدنا وحبيبنا محمد الببي المكرم والرسول الممجد وعلى اله لهائل أولي الرشاد والتوفيق وأصحابه ذوي السداد الساد

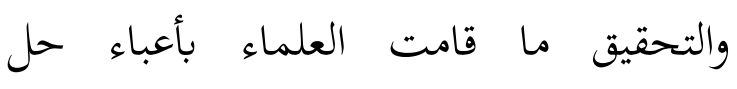
المشكلات وذكر الله ذاكر فن البكور والعشاء 
وبعد. فيقول فقير عفو ربه الملك الأوحد عطاء الله بن أحمد بن عطاء الله بن أحمد غفر الله له ذنوبه وأفاض عليه من الرضوان ذنوبه قد ورد

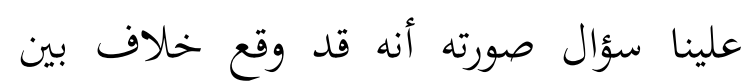
طلبة العلم من بلادنا الجاوي في تحيز الجرم هل صل

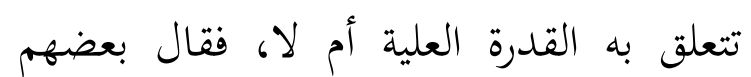
لاتتعلق به لأنه واجب للجرم والقدرة انما تتعلق

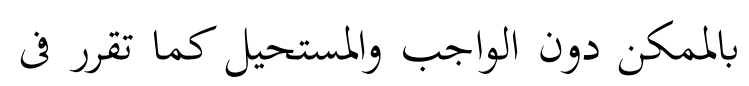
علم الكلام وقال بعضهم تتعلق به القدرة لأنه

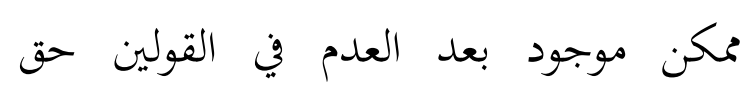
وتحقيق. الجواب أن الواجب أما واجب لذاته لئ لعولين كالباري تعالى أو واجب لغيره مع كونه ممكنا في نفسه كصفات الباري تعالى وكالعقول والنفوس المجردة عند الحكماء فاها ممكنة في تئن نفسها واجبة لذات الباري تعالى لاستنادها

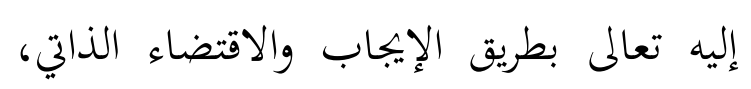
والقول بأن صفاته تعالى واجبة لذاتها أي نفسها قول باطل ورأي عاطل، لأن الواجب لذاته هو ما يكون وجوده مقتضي ذاته ولا

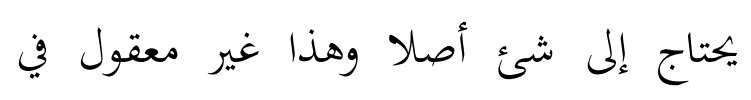
الصفات ضرورة أغما معان لاتقوم بنفسها، إنان فتحتاج إلى ذات الباري بل هو شرك لأن

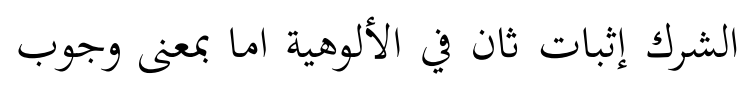

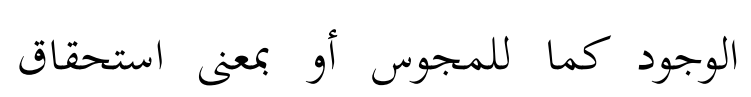

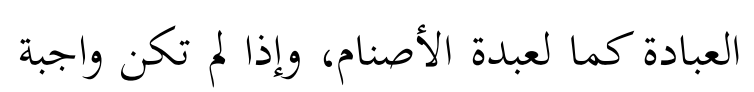

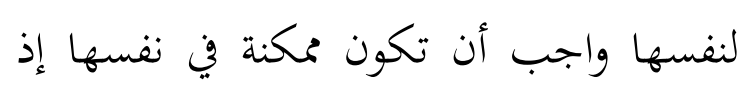

لا واسطة بين الوجوب الذاتي والإمكاني الذاتي نعم لا ينبغي إطلاق الإمكان عليها لأنه توهم الحدوث على ماشتهر من قولم كل ممكن حادث بل يقال هي واجبة لما ليس عينا في ماتئ

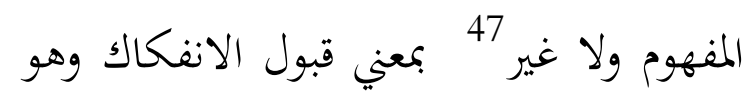

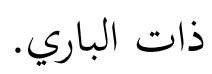

فان قلت "فما تصنع في هذه القادة؟" قلت "هي خخصوصة بالممكن الصرف الذي لم يعرض له وجوب أو إمتناع بالغير كما صرح بذلك المحققون كإمام الحرمين 48 والغزالي 49 والإمام الرازي 50 والبيضاوي 51 47

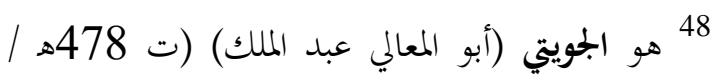
1085م) : فقيه شافعيّ ومتكلم. (المنجد في الأعلام، المبل دار المشرق- بيروت، ص 208) : 2085.

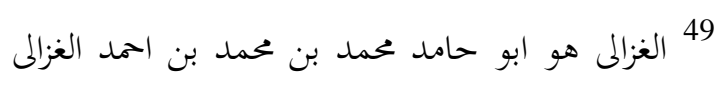

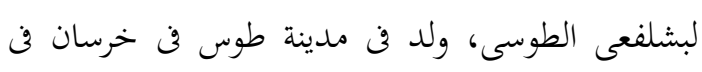

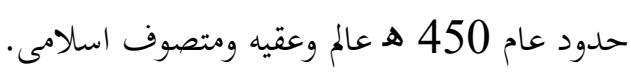
50

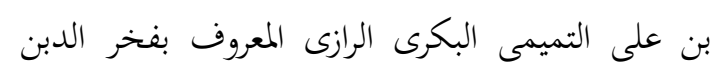

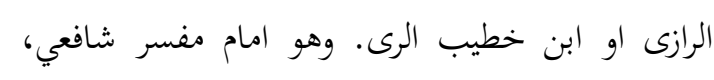

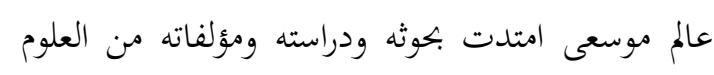
الإنسانية اللغوية والعقلية الى العلوم البحتة فن: الفيزيا، الرياضيات، الطب، الفلك.

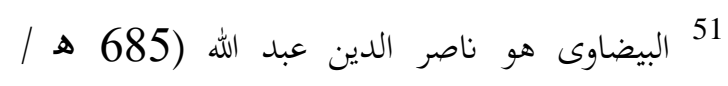

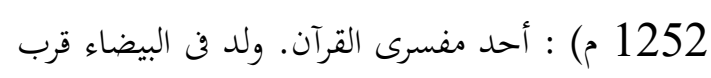

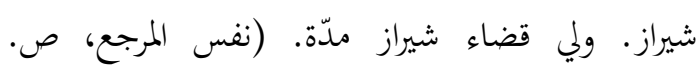




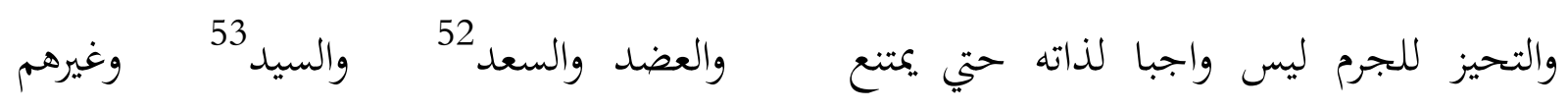

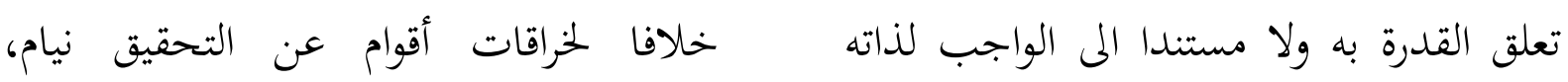

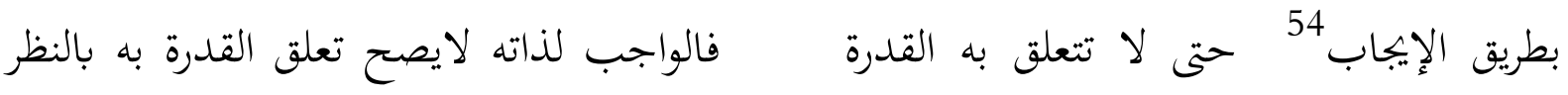

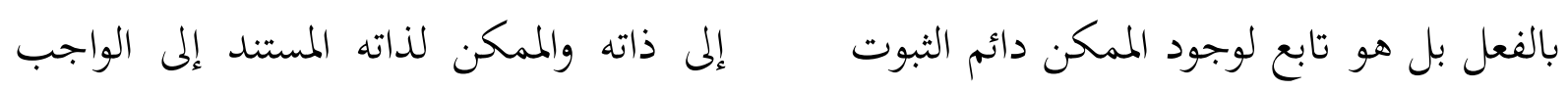

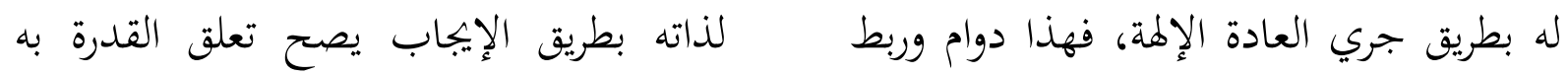

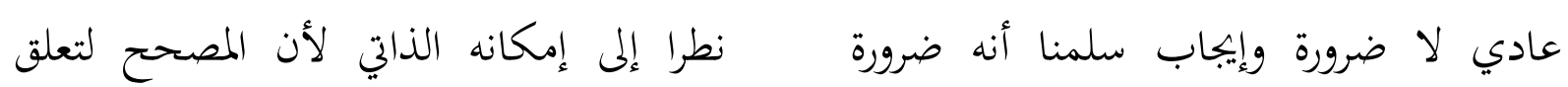

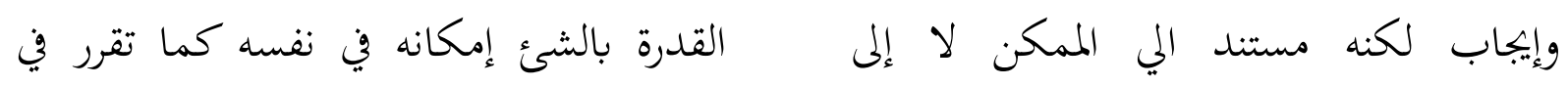

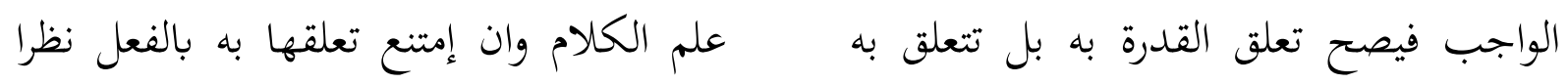
إلى الوجوب بالغير وهذ معنى قول المتكلمين

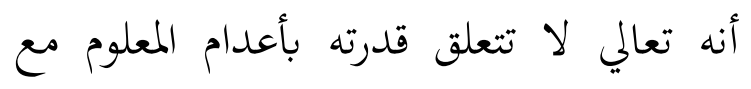

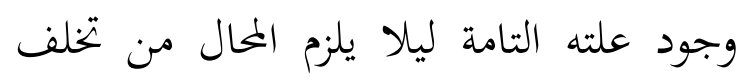

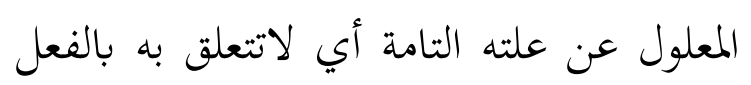
نظرا إلى هذا العارض وإن صح تعلقها به بالنظر إلى ذاته فها هنا مقامات أحدهما صحة التعلق مناطه الإمكان الذاتي، وإن كان هناك وجوب أو إمتناع بالغير وتعلق بالفعل ومناطه إلفان

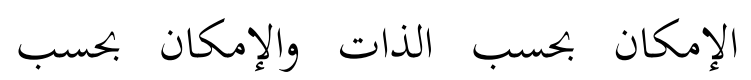
الذات لا ينافيه الوجوب أو الامتناع بالغير

52 هو سعد الدين الحمويّ (ت 650 هـ / 1252 م) : متصوف خرسانيّ. نسبته الى جدة محمّية. نشأ في جوين.

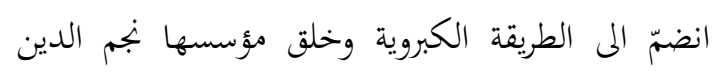

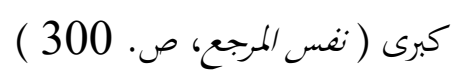

53 هو سيد أحمد لطفى ( 1872 - 1963 ) ) : أديب صني

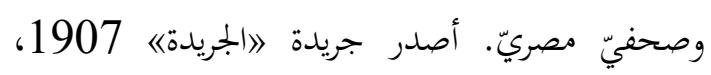

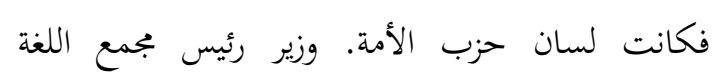

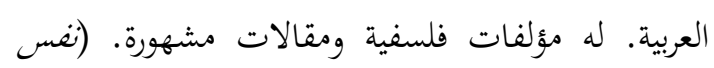
المرجع، ص. 319).

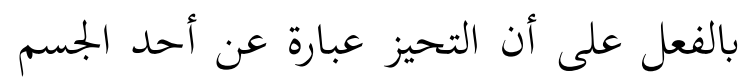
قدر ذاته من الفراغ الموهوم على ما عليه المتكلمون أو المحقق كما عليه الفلاطون 55 على الخلاف في وجود الخلاء أو السطح

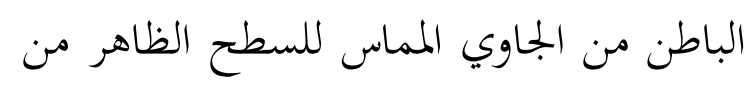
الموي كما عليه أرسطو.

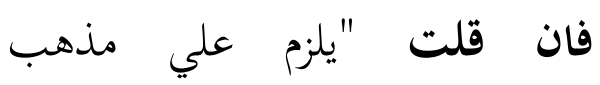
أرسطو 56 عدم تناهي الأجسام وهو ظاهر" 54 54 55 أفلاطون (427-347 ق. م) م : من مشاهير فلاسفة : الاجات اليونان. تلميذ سقراط ومعلّم أرسطو. درس عى بـ بستان

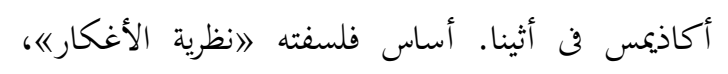

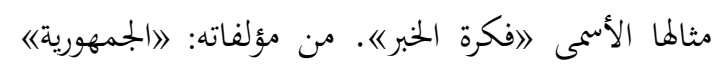

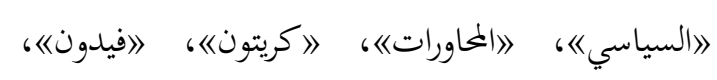

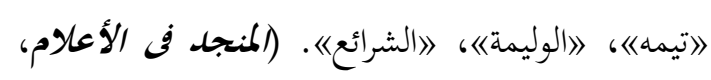

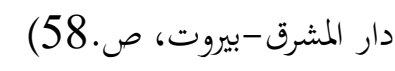

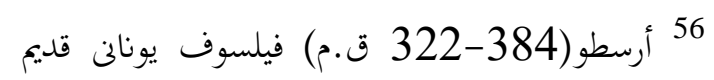
كان أحد تلاميذ أفلاطون ومعلم الاسكندر الأكبر.

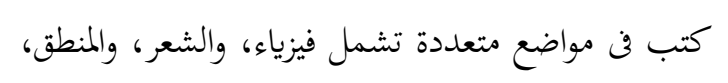


قلت "الأجسام تنتهى إلى جسم ذي وضع أي قابل للإشارة الحسية وليس له حيز وذلك الجسم هو الفلك الأعظم المحيط بالعالم المحد

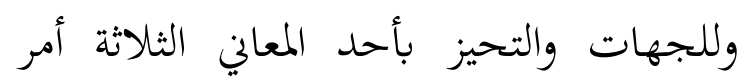
إعتباري عدمي لا تتعلق به القدرة سلمنا أنه

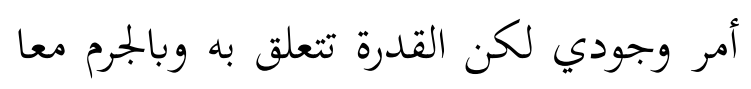
فيكون تعلقها به تعلقا بالممكن لذاته ولغيره أي الممكن الصرف الخالي عن الوجوب بالغير نعاليه كالإمتناع به".

فان قلت "هل يصح تعلقها بعدمه حالة وجود الجرم؟" قلت "نعم يصح تعلقها به

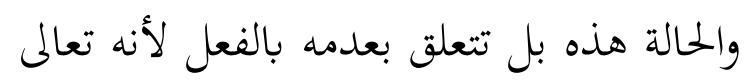

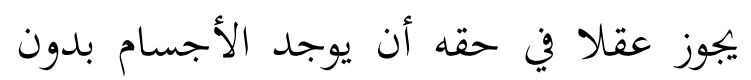
تحيز كالمجردات عند من يقول بثبوتا فاها موجودات لا تحيز لها ولا خفاء في أنه يجوز عليه بعض الأعيان ما يجوز على البعض الآخر

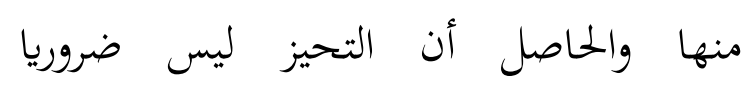

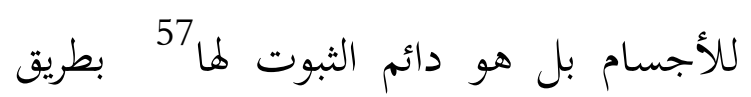

$$
\text { جري العادة الإلهية". }
$$

فان قلت "ماذكرته من تعلق القدرة

بالعدم ينافي ما عليه المحققون من أن القدرة

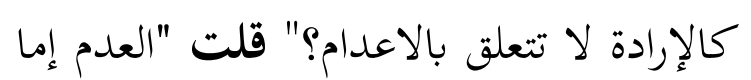

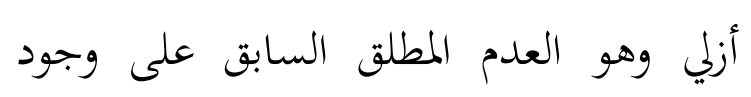

وعبادة الحيوان، والاحياء، واشكال الحكم wikipedia) Indonesia.mht) 57
الممكن وهذا لا تتعلق به القدرة والإرادة ليلا

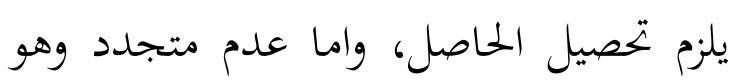
العدم المقيد بالإضافة إلى الممكن وهو الحيل واصل العدم اللاحق للوجود كعدم زيد بعد وجود لأن وجود كل ممكن محفوف بعدمين، عدم سابق

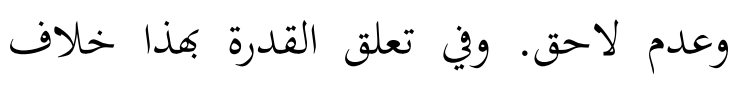
فقيل تتعلق به فيحصل بها بعد ان لم يكن حاصلا وقيل لا يتعلق به لأن أثر القدرة والإرادة لا يكون إلا حادثا والحادث موجود بعد عدم وقبول الشئ للأثر الحادث فرع وجود القابل في نفسه ولا وجود للعدم بل هو نقيض الوجود، فلا يكون قابلا لأثر القدرة الحادث

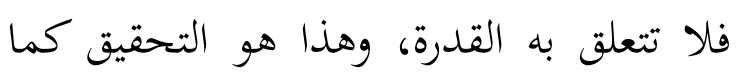
عليه المقققون ويؤيده قوله صلي الله عليه وسلم (ما شاء الله وشئت فقال بل ماشاء الله وحده) 58 فأسند وجود الممكن إلى تلى تعلق ماءل

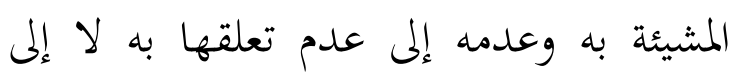
تعلقها به، ويقابل الحادث القديم وهو موجود لم يسبق وجوده عدم، وأما الأزلي فهو مالا ابتدأ له موجودا كان كالباري تعالي أو غير وجوده ولام موجود كالاعدام المطلقة الأزلية، ويقابل الأزلي

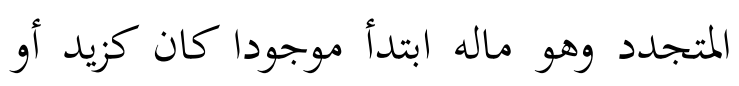
معد وما كعدمه اللاحق لوجوده فالحدوث

58 حديث أخرجه أحمد (1863)، باب بداية مسند عبد الله بن العباس. 
والقدم لا يكونان إلا زمانيين أي بحسب الوجود لا بحسب الذات، وهذا ما عليه المتكلمون وذهب الفلاسفة الى أن كلا من وهود العدم والحدوث ينقسم الم الذاتي والزماني اما

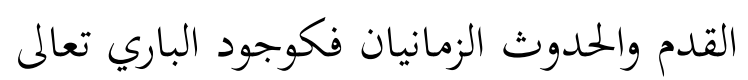
وكوجود زيد، واما القدم الذاتي فكوجود الباري واما القدم الزماني دون الذاتي فكوجود صفات وليات الباري تعالى، واما الحدوث الذاتي دون الزماني

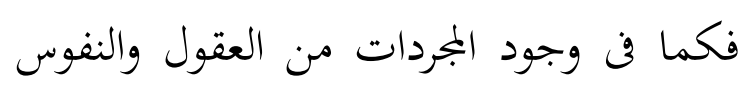
عندهم واما الحدوث الزماني فكوجود زيد كما

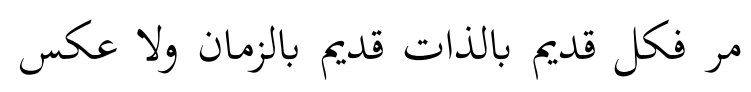

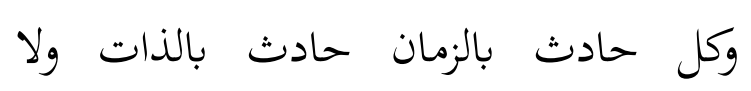
عكس.

فان قلت "ما وجه قدم صفات

الباري تعالى مع أها ممكنه في نفسها؟" قلت "وجهه أها مستنده إلى ذات الباري تعالي لئل بطريق الإيجاب والإقتضاء الذاتي فوجودها مقارنا لوجوده تعالي والإلزم تخلف المعلول عن

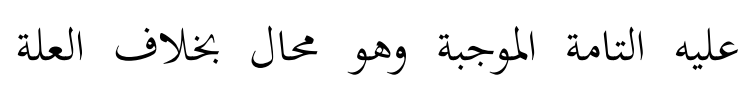

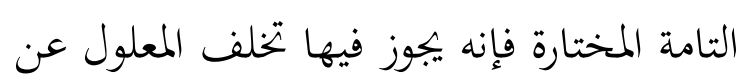
العلة التامة كوجوده العالم بالنسبة الى الله تعالي."

فان قلت "مالفرق بين إيجاب

الصفات حيث عد كما لا وبين إيجاب العالم

حيث عد نقصا يجب تنزيه الباري تعالى عنه؟" إيكاب العابم
قلت "ايجاب الصفات إيجاب كمالي ذاتي يقضي عدمه إلى اتصاف الذات بأضداد

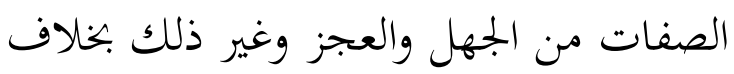
إيجاب العالم، فانه لا يفض عدمه إلى نقص فن ونمئ ذات الله تعالي بل يفضي وجوده إلى نقص كما هو ظاهر ولذا كان الله تعالى موجودا في الأول ولا عالم قال صلى الله عليه وسلم (كان

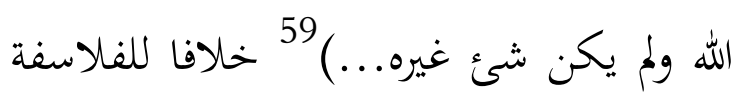
حيث ذهبوا إلى قدم العقول والنفوس والأفلاك بموادها وصورها بل إلى قدم الهيولي والصورة، وأن العالم مركب منهما لا من الجواهر الفردة

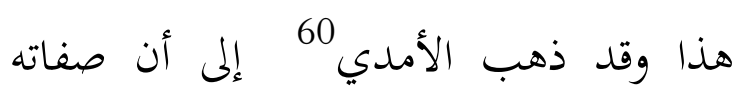
تعالى مستند إلى ذاته تعالي بطريق الإختيار كباقي الممكنات حذرا من الإيجاب المنافي الإختيار الذي هو نقص واعترض عليه بأنه يلزم أن تكون صفات الباري تعالي حادقة ضرورة أنه لا بد أن تكون معدومة في زمان القصد والاتحاد والإلزم تحصيل الحاصل وإجاب بأن تقدم الإيجاد على وجود الصفات بالذات لا بالزمان فيكون وجودها كإيجادها

59 قطعة من حديث أجرجه بخاري (2953)، باب: ما جاء فن قول الله تعالى وهو الذى بيدأ الخلق.

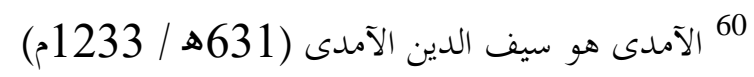

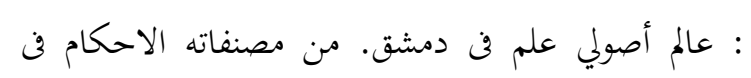
اصول الأحكام. (المنجد في الأعلام) دار المشرق-بيروت

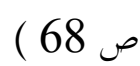


قديما غير مسبوق بالعدم ورفع بأنه يلزم تحصيل الحاصل وهو محال، وأجيب من هذا الدفع بأن المحال إيجاد الموجود بوجود سابق على الإيجاد

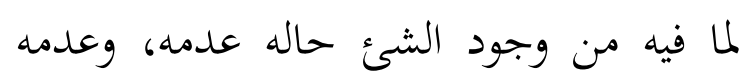

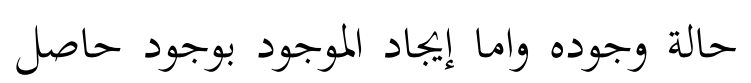
بذلك الإيجاد فليس بمحال كما لا يخفى وبهذا

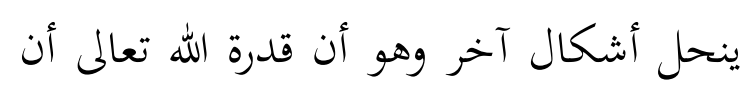

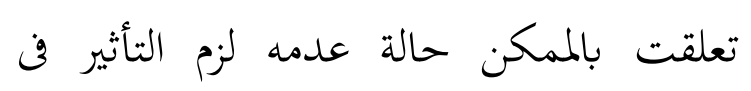

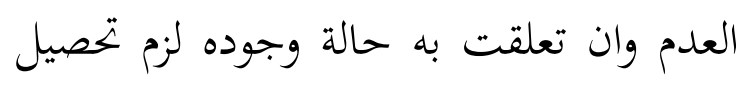
الجاهل وكالاهما محال لكن يرد عليه من جملة

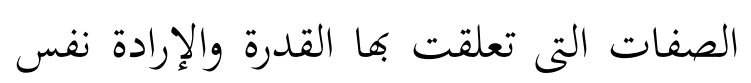
القدرة والإرادة، فيلزم تأثير الشئ في نفسه وهو

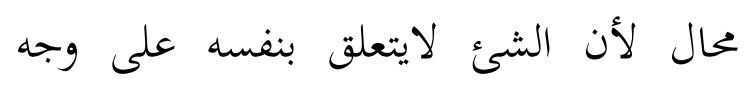
التأثير فهو قول باطل ورأي عاطل لابجال للعقل فيه. اللهم إلا أن يجعل وجود الصفات

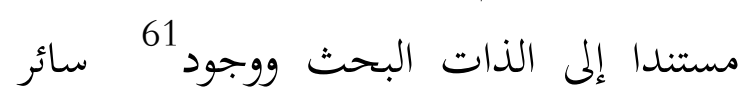
الممكنات مستندا إلى الذات بتوسط القدرة والإرادة حتى لايلزم المحال من تأثير الشئ في بن نفسه واحترز منا بقولنا على وجه التأثير عن لإلن

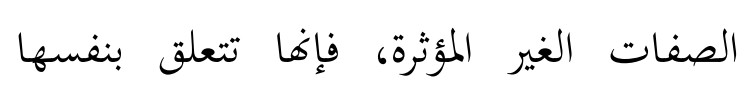
كيتعلق علم الله بنفسه كغيره فإنه صفه الكشاف لا تأثير.

فان قلت "ما تحقيق كون الإمكان

الذاتي لاينافيه الوجوب أو الإمتناع بالغير وما
توضيحه؟" قلت "اما الأول فلأنه لا تناقض عند اختلاف الجهة والإعتبار، وأما الثانى فلما تقرر عند المناطقة من جواز الإيجاب بالقول

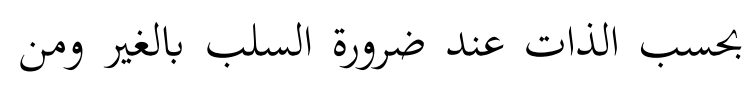
جواز السلب بالفعل بحسب الذات عند ضرورة بالغير نحو كل كاتب متحرك الأصابع

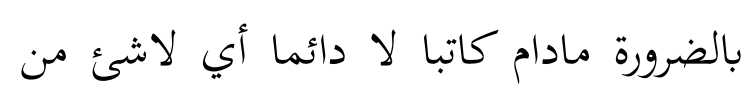
الكاتب يتحرك الأصابع بالفعل بحسب الذات ونهو لاشئ من الكاتب بساكن الأصابع

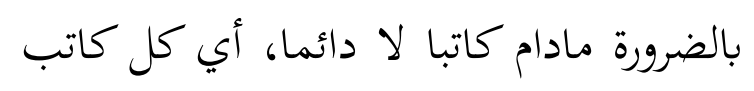
ساكن الأصابع بالفعل بحسب الذات ولنقتصر علي هذا القدر ففي تبصرة لمن ينتصر وتذكرة لمن يتذكر، وعلى الله الكريم إعتمادي وإليه تفويض واستنادي. بلغ تحريره في 62 الثامن والعشرين من شهر صفر المبارك سنة ثمانين ومائة وألف من الهجرة النبوية المكية المدنية على ربها من ربه أفضل الصلاة وأكمل التحية على يد مؤلفها فقير عفو ربه الملك الأوحد عطاء الله بن أحمد بن عطاء الله بن أحمد غفر الله ذنوبه وأفاض عليه من الرضوان ويوفيه وغفر له واله ومشايخه والمسلمين أجمعين أمين

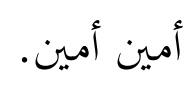

الأفكار الهامة التى وردت فى النص

$$
61 \text { في النص مكتوب : ووجو }
$$


بعد قراءة هذا النص نستخرج أهم الأفكار وهي :

أ) معنى التوحيد لا اله الا الله

لا اله الا الله هي كلمة الإسلام لا لا لهاه

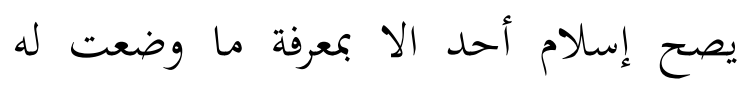
ودلت عليه وقبوله ولانقياد للعمل له، وهي

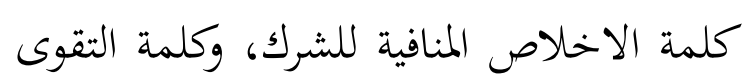
التى تقي قائلها من الشرك بالله فلا تنفع قائلها الا بشروط سبعة. الأول : العلم بمعناها نفيا واثبات، والثاتى : اليقين وهو كمال العلم بها

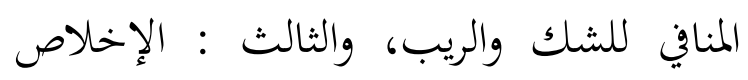
المنافي للشرك، والرابع : الصدق المانع من النفاق، والخامس : المحبة لهذه الكلمة ولما دلت عليه والسرور بذلك، والسادس : الانقياد

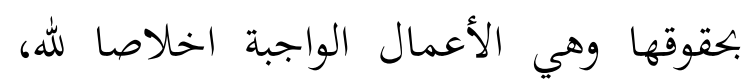
والسابع : القبول المنافي للرد. تعنى لا اله الا الله هو عبادة الله وحده لعده

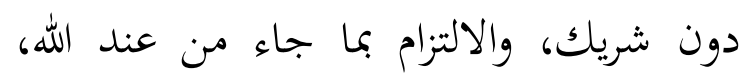
فالألوهية في جانب الله تقتضى العبودية في كل

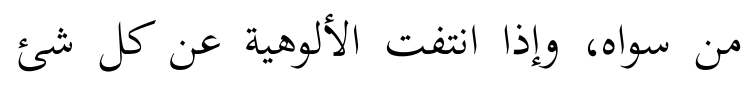
وكل أحد وكل كائن فن هذ الوجود كله، وثبتت لله وحده، فمعنى ذلك أن الإله الذى آلى يعبد بكق هو الله، ولا يعبد سواه، لأن كل من وحن لهنئ

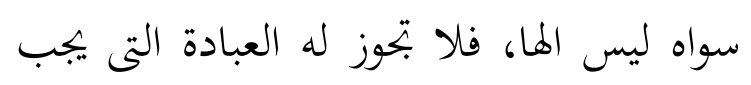
أن تتمحض لله وحده شريك.
ب) الاعتقاد عند المجوس، وعبدة الاصنام،

والمعتزلة

الالوهية تطلق تارة على صفة وجوب

الوجود وتارة على صفة استحقاق العبادة.

والتوحيد باعتقاد نفي الشركة فن كل من ونس

الصفتين، والاشراك باعتقاد الشركة في احد لئد

الوصفين. والاله يطلق على ثلاثة معان، على ولى باعنى

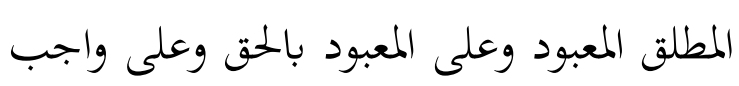
الوجود. - الو.

كما وقع للمجوس وهو يعتقد أن الله

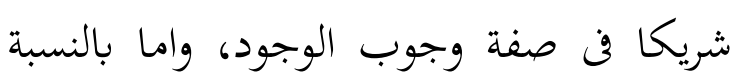
لعبدة الاصنام وهو فيعتقدون أن الله له شركاء في صفة استحقاق العبادة، وأما بالنسبة للمعتزلة فإنه اثبات شركاء لا يخص في الخالقية لله تعالى حيث زعمو أن العبد يخلق أفعاله الاختيارية فليس من الاشراك في شئ. ج) من الناحية اللغوية كلمة لا اله الا الله تدل على قصر حقيقي وهو أن يختص المقصور عليه بحسب الحقيقة والواقع بإلا يتعداه الى غيره أصلا. واعراب لا اله الا الله:

لا : حرف النافية للجنس اي لنسبة صفته وحكمه اليه اله : اسمها مبني على الفتح لتضمنية معنى اليه الحرف وهو من الاستغراقية 
لا من اله الا الله : في محل نصب لاها من

$$
\text { اخوان انّ وخبر لا محذوف }
$$

الا : حرف استثناء او اسم استثناء بمعنى غير

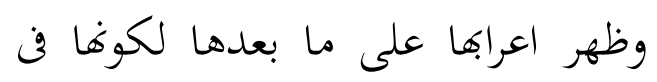

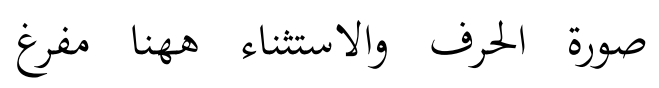

متصل لدخول المستثنى، والمستثنى منه

$$
\text { اعنى مطلق الاله }
$$

الله : مرفوع على انه يدل من الضمير فن هبر

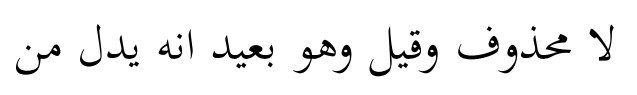

$$
\text { محل اسم لا لاست }
$$

لذا فقول (لا اله الا الله) فو (لا) نافية

للجنس و(الإله) هو المألوه بالعبادة وهو الذي تألهه القلوب وتقصده رغبة اليه في حصول نفع أو دفع ضرٍ كحال من عبد الأموات

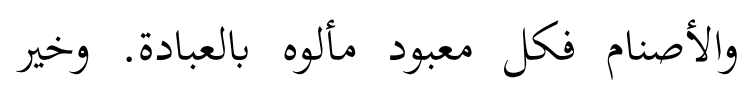
(لا) المرفوع محذوف تقديره : حق، وقوله :

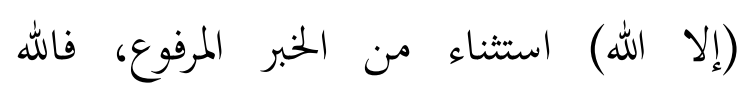
سبحانه هو الحق وعبادته وحده هي الحق

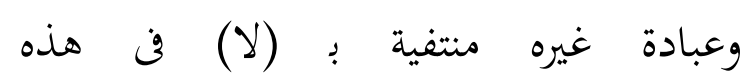
الكلمة.فإلهية ما سواه باطلة. د) القسمة فى التوحيد وان التوحيد ينقسم على ثلاثة اقسام:

اولا : توحيد العوام، وهو عبارة عن اثبات

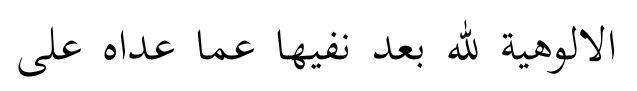

ما هو مدلول كلمة التوحيد لا اله الا الله

ثانيا : توحيد الحواص، وهو عبارة عن

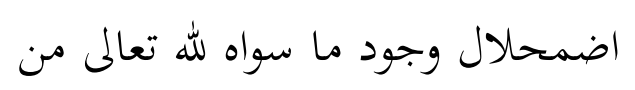
الكائنات بجيث لايشاهد بقلبه الا وجود ماه لهان وجود الله تعالى وحده كما لا يشاهد

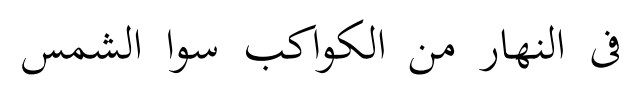
وذلك لانه لما استولى على قلوب عباد

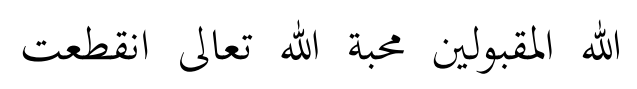
عقولهم عما سواه وذهلت عما عداه فلم ييق لمم شعور بالعلوم زالادراكات ولا بوجود شئ من الكائنات فياذا لئا

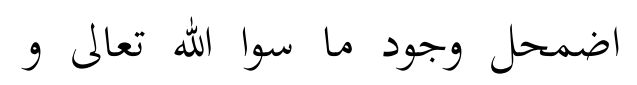

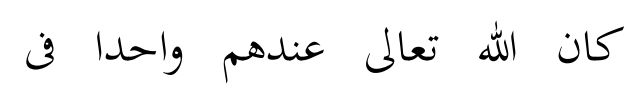
الوجود كما انه واحد في الالوهية.

ثالثا : توحيد أخض الخواص، وهو نفي

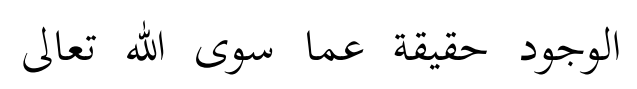
واثباته له تعالى وحده وذلك بأن يراه

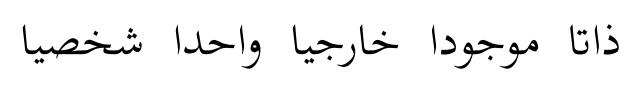
وما سواه امور عدمية ظهرت فن الحس بسبب اشراق نوره وجوده تعالى عليها وتعلق بها.

\section{الخاتمة}

مخطوطة عقد التوحيد في تحقيق كلمة التوحيد للشيخ عطاء الله بن أحمد بن عطاء 
الله بن أحمد المصرى الأزهرى من المخطوطات التى تتحدث عن موضوع هام جدا وهو عقيدة

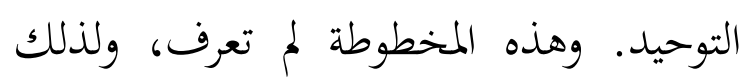
فقد اجتهلد في تحقيقها حتى تعم الفائدة، خاصة لمن يريد أن يعرف حقيقة قول الا اله الا الله

وتحقيق هذا النص يدخل ضمن التعريف بالتراث القديم ونشره حتى يعلمه كثير من الناس.

في هذا الأيام نحن في أشد الحاجة الى

نشر مثل هذه الموضوعات التى تساعد على تقوية عقيدة المسلمين. والتوحيد يطمئن قلوب الناس ويسلمه من الضلال والشرك، وله أثر كبير في تكوين السلوك.

وهذه المخطوطة بها علم نافع ومفيد

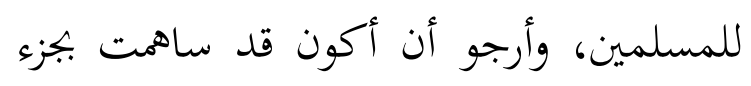

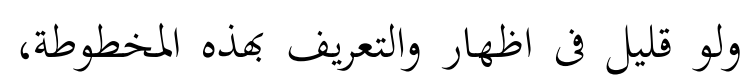
لأغها جزء من تراث المسلمين. مراجع البحث أ- إجع العربية

أحمد الهاشمي، جواهر البلاغة فى المعانى والبيان والبديع، بيروت: دار الفكر

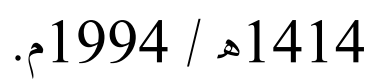

الشيخ مصطفى الغلايينى، جامع الدروس العربية، بيروت: المكتبة العصرية.
فؤاد نعمة، ملخص قواعد اللغة العربية، بيروت: دار الثقافة الاسلامية.

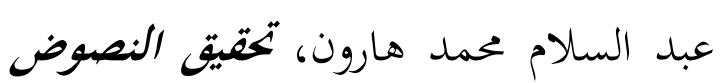
ونشوها ، القاهرة: مكتبة السنة، ط.5 . . عبد الهادى الفضلى، تحقيق التراث، جدة: مكتبة العلم، 1982م، ط المائ العطى، 1.

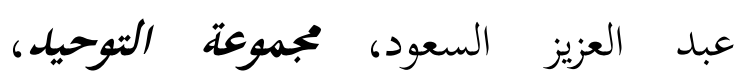
النجدية.

عبد الستار الحلوجى، المخطوط العربي، القاهرة: الدار المصرية اللبنانية،

$$
1423 \text { هـ، ط } 1 \text {. } 14
$$

عليّ ابن علي بن محمد بن أبي العزّ الدمشقي، شرح العقيدة الطّحاويّة، بيروت:

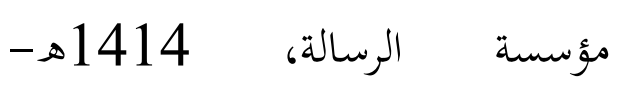

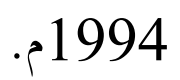

عمر رضا كحاله، معجم المؤلفين، تراجم مصنفى الكتب العربية، بيروت: مكتبة المثنى ودار أحياء التراث العربى، المجلد الثالث.

لويس معلوف، المنجد فى الأعلام، بيروت: دار المشرق، 1986، ط 23. اسماعيل مروة، فى المخطوطات العربية، بيروت-لبنان: دار الفكر المعاصر.

محمد بن عبد الوهاب، مجموعة التوحيد، لئل مكتبة الرياض الحديثة. 


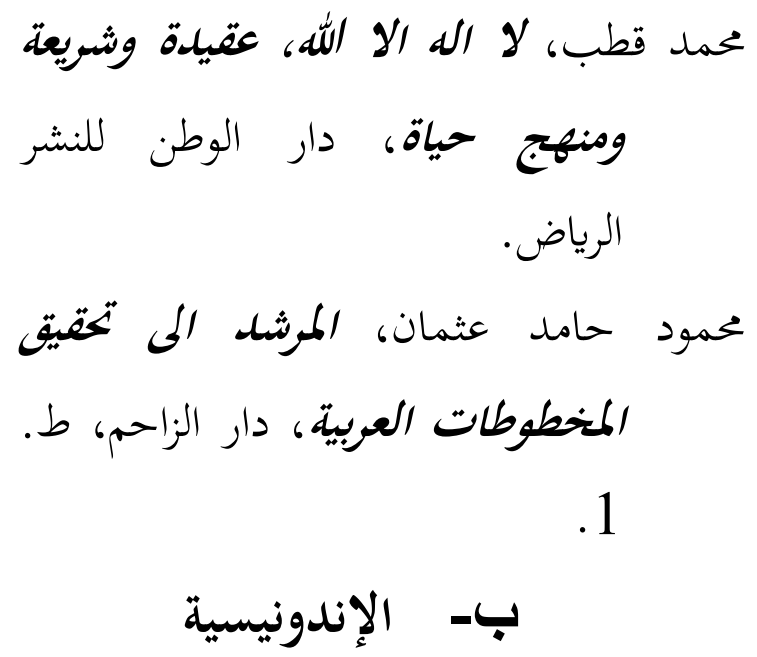

Abu Zahrah, Imam Muhammad, Aliran Politik Dan Aqidah, Jakarta: Logos Publishing House 1996.

Kumpulan Makalah Simposium Tradisi Tulis Indonesia, Tradisi Tulis Nusantara, Masyarakat Pernaskahan Nusantara 1997.

H. Hart, Michael, 100 Tokoh Paling Berpengaruh Sepanjang Masa, Karisma Publishing Group, 2005.

Lubis, Nabilah, Naskah, Teks Dan Metode Penelitian Filologi, Yayasan Media Alo Indonesia, Jakarta: 2001, Cet Ke2.

Nasution, Harun, Teologi Islam AliranAliran Sejarah Analisa Perbandingan, UI-Press, 2002.

Nata, Abuddin, Akhlak Tasawuf, Jakarta: PT Raja Grafindo Persada, 1996.

Sunarto, Ahmad, Kamus Al-Fikr, Surabaya : Halim Jaya, 2002, cet.ke-1.

Syadali, Ahmad dan Mudzakir, Filsafat Umum, Bandung : CV Pustaka Setia, 2004.

S.O. Robson, Prinsip-prinsip Filologi Indonesia, Jakarta: RUL, 1994

T.E. Behrend (ed); Katalog Induk NaskahNaskah Nusantara Perpustakaan Nasional RI; Jakarta : Yayasan Obor Indonesia \& Ecole Francaise D'extreme Orient, 1997 ; jilid 4. 
